\title{
Glycobiology Modifications in Intratumoral Hypoxia: The Breathless Side of Glycans Interaction
}

\author{
Antônio F. Silva-filho ${ }^{a}$ Wanessa L.B. Sena ${ }^{a}$ Luiza R.A. Lima ${ }^{a, b}$ Lidiane V.N. Carvalho ${ }^{a}$ \\ Michelly C. Pereira ${ }^{a, c}$ Lucas G.S. Santos ${ }^{a}$ Renata V.C. Santos ${ }^{a}$ Lucas B. Tavares $^{a}$ \\ Maira G.R. Pitta ${ }^{a, d}$ Moacyr J.B.M. Rêgo ${ }^{a, d}$ \\ aLaboratory of Immunomodulation and New Therapeutic Approaches (LINAT), Center for Research on \\ Therapeutic Innovation - Suely Galdino (NUPIT-SG-UFPE), Recife, 'bFaculdades Integradas de Patos, \\ Patos, PB, 'Department of Physiology and Pharmacology, Federal University of Pernambuco (UFPE), \\ Recife, ${ }^{\text {DDepartment }}$ of Biochemistry, Federal University of Pernambuco (UFPE), Recife, Brazil
}

\section{Key Words}

Glycobiology - Glycosyltransferases - Hypoxic microenvironment - Cancer - Biomarker • Carbohydrate metabolism

\begin{abstract}
Post-translational and co-translational enzymatic addition of glycans (glycosylation) to proteins, lipids, and other carbohydrates, is a powerful regulator of the molecular machinery involved in cell cycle, adhesion, invasion, and signal transduction, and is usually seen in both in vivo and in vitro cancer models. Glycosyltransferases can alter the glycosylation pattern of normal cells, subsequently leading to the establishment and progression of several diseases, including cancer. Furthermore, a growing amount of research has shown that different oxygen tensions, mainly hypoxia, leads to a markedly altered glycosylation, resulting in altered glycanreceptor interactions. Alteration of intracellular glucose metabolism, from aerobic cellular respiration to anaerobic glycolysis, inhibition of integrin $3 \alpha 1 \beta$ translocation to the plasma membrane, decreased 1,2-fucosylation of cell-surface glycans, and galectin overexpression are some consequences of the hypoxic tumor microenvironment. Additionally, increased expression of gangliosides carrying $\mathrm{N}$-glycolyl sialic acid can also be significantly affected by hypoxia. For all these reasons, it is possible to realize that hypoxia strongly alters glycobiologic events within tumors, leading to changes in their behavior. This review aims to analyze the complexity and importance of glycoconjugates and their molecular interaction network in the hypoxic context of many solid tumors.

(C) 2017 The Author(s)

Published by S. Karger AG, Basel
\end{abstract}

\section{Introduction}

Many molecular mechanisms are involved in the modification of macromolecules. Among them, glycosylation represents an essential mechanism for physiological processes.

A. F. Silva-filho and W. LB. Sena contributed equally. 
Glycosylation can be defined as the process that produces glycosidic linkages of saccharides to other saccharides, lipids, or proteins. Carbohydrates can be covalently attached, usually via nitrogen (N-linked glycosylation) or oxygen (O-linked glycosylation) linkages [1].

Glycans are involved in the development, growth, functioning, and survival of the organism that synthetized them. They are usually associated with cellular mechanisms involving cell-cell and cell-matrix interactions, immune response, and signal transduction $[2,3]$. It is estimated that more than $50 \%$ of human proteins have a carbohydrate portion, and that this process represents one of the most important protein post-translational modifications [4, 5].

Aberrant glycosylation has been largely recognized as a hallmark of neoplastic tissue and allows the acquisition of all the hallmarks of cancer [6]. During cancer progression, changes in the glycosylation patterns of cell surface and secreted glycoproteins, leading to tumor proliferation, invasion, epithelial-mesenchymal transition, metastasis, and angiogenesis have been observed [7-10]. The crucial role of glycans in a cancer context is also reflected in its use as a biomarker, since most tumor markers approved by the Food and Drug Administration (FDA) are glycoproteins or glycan antigens [6].

Glycans are unique and advantageous as marker molecules because they are capable of reflecting behavioral and microenvironment features of tumor, including hypoxia [11]. Most solid tumors present areas with various degrees of hypoxia, due to rapid proliferation and abnormal angiogenesis [12]. In hypoxic microenvironments, hypoxia-induced factors (HIFs) play a key role in the upregulation of several genes responsible in the promotion of cancer cell survival $[13,14]$. In normal oxygen conditions, HIF- $1 \alpha$ is degraded via ubiquitinproteosome, a process regulated by several proteins, among them Prolyl-4-hydroxylase 2 (PHD2) [15]. However, its levels accumulate under hypoxia conditions [16].

Cells selected by hypoxic stress are associated with tumor progression and malignancy [17]. Patients with hypoxic tumors, such as breast, endometrial, and liver, have a worse prognosis [18-20]. Moreover, hypoxia and HIF-1 $\alpha$ overexpression are related to increased metastasis and resistance to conventional therapies, key factors that are responsible for cancer-related deaths [21,22].

Due to changes in oxygen levels, cancer cells can switch their energy metabolisms. The Pasteur Effect is observed in normal oxygen levels, which results in the activation of oxidative phosphorylation and the inhibition of glycolysis. However, cancer cells develop a hypoxia-induced scape mechanism, which switches oxidative phosphorylation to glycolysis (also known as the Warburg effect) to support high proliferation [23, 24]. In order to target tumor cells with this profile, new therapeutic strategies that act on glycolytic pathway are being developed. 2-deoxy-D-glucose (2-DG), a glucose analogue, inhibits glycolysis in tumor cells growing under hypoxia, leading to cell death. Under normoxia conditions, 2-DG is not capable of affecting energy production, but interferes with N-linked glycosylation [25-27].

In the currentreview, we will discuss the changes in glycosylation induced by intratumoral hypoxia in epithelial tumors and their biological effects. It is now known that bone marrow also presents hypoxic areas that can enhance leukemia progression [28]. However, this article will only focus on studies that mimic hypoxia in solid tumors. Identification of hypoxia-associated changes in glycosylation is important to better characterize the tumor microenvironment and can be further used for biomarker development and therapeutic interventions.

\section{Hypoxia Reprogramming Carbohydrate Metabolism}

Hypoxia induces a reprogramming of cell respiration and ensures tumor success, beyond consequences imposed by uncontrolled proliferation, all this through regulation of gene expression to induce a tumor antianoxia effect [29]. The Warburg Effect was discovered more than 80 years ago, by the scientist Otto Warburg, who observed that glucose consumption and lactate conversion were higher in tumor cells when compared to normal cells [30]. 
Tumor tissue is sustained by glycolytic activity, even under normoxia. This is associated with dysfunction of mitochondria and changes in enzyme pattern, especially an enzymatic increase in glycolytic activity. In the Warburg Effect, tumor cells avoid complex processes, such as tricarboxylic acid cycle and oxidative phosphorylation (OXPHOS), and perform anaerobic glycolysis [31]. Glycolysis is a low energy yield process but is more simple and fast. Therefore, glycolysis is exacerbated in tumor tissue and increases with tumor progression [32].

HIF-1 also regulates aerobic glycolysis in order to attend to the biosynthetic demands of cancer cells and to avoid damage due to hypoxic stress [33]. Even under normoxic conditions, high lactate and pyruvate levels generated by active tumor glycolysis can promote HIF-1 $\alpha$ stabilization, preventing their degradation via ubiquitin-proteasome [34]. HIF-1 $\alpha$ alters the expression profile of several specific glycolytic molecules involved, directly or indirectly, with glucose metabolism and the obtaining of ATP (adenosine triphosphate) [33].

Expression of glucose transporter GLUT1 and GLUT3 carriers is increased in hypoxia, probably due to its importance in the regulation of glycolysis $[35,36]$. The rate of glucose transport by GLUT-1 is altered in situations in which the metabolic rate needs to be adjusted, such as in cell division (mitosis and meiosis), differentiation, transformation, and nutrient starvation. Increased GLUT-1 expression correlates with poor survival and poor therapeutic outcomes in cancer [37]. However, the first and rate-limiting enzyme in glycolysis is hexokinase (HK), highly expressed in many tumors, and is responsible for ensuring the necessary energy supply to malignant tumors. Two isoforms of monomeric HK (HKI and HKII) are target genes of HIF1- $\alpha$ [38]. HKI and HKII can inhibit apoptosis and dissuade the flow of mitochondrial ATP to hexose phosphorylation, thereby contributing to the survival advantage of tumor cells [29,39].

Pentose Phosphate Pathway (PPP) represents a glucose degradation route that plays a vital role in meeting cellular demands for anabolic biosynthesis and providing anti-oxidative defense [40]. Compared with normal epithelial cells, PPP is known to be upregulated in tumor cells. It was shown that G6PD (Glucose-6-phosphate dehydrogenase), a rate-limiting enzyme of PPP, is dynamically modified with an 0 -linked $\beta$-N-acetylglucosamine sugar in response to hypoxia in several lineages, such as hepatocarcinoma, melanoma, and breast cancer [41]. Inversely, it was found that expression of PPP enzymes, in particular G6PD and 6-phosphogluconate dehydrogenase, is downregulated by acute hypoxia and upregulated by oxygenation in glioblastomas cell lines, while glycolysis enzymes are downregulated [42].

In solid tumors, also during hypoxic condition, pyruvate dehydrogenase kinase 1 (PDK1) is activated by HIF- $1 \alpha$ and phosphorylates serine residues of pyruvate dehydrogenase (PDH) at three different sites, inhibiting its activity. Therefore, HIF-1 indirectly blocks the conversion of pyruvate to acetyl-CoA (acetyl coenzyme A), and, thus, prevents ATP production via the TCA (tricarboxylic acid) cycle and oxidative phosphorylation in mitochondria [43, 44]. Since PDK1 can reduce ROS (Reactive Oxygen Species) production in cells, the HIF-1 $\alpha$ pathway, thus, protects cell from ROS damage through PDK-1 induction under hypoxic stress. HIF$1 \alpha$ pathway also optimizes cancer cell respiration by regulating the switch of cytochrome oxidase (COX-4) subunits [45, 46]. This metabolic adaptation includes increased expression of glucose transporters and glycolytic enzymes, combined with mitochondrial remodeling [47]. Moreover, HIF-1 $\alpha$ induces miR-210 transcription and decreases the expression of ironsulfur cluster assembly proteins (ISCU) and COX-10 in breast, colon, and esophageal cancer cell lines. These are two important elements of the mitochondria electron transport chain and TCA cycle (Fig. 1) [48].

These results collectively demonstrated that HIF- $1 \alpha$ reduces mitochondrial respiration under hypoxia conditions, which inhibits aberrant electron leakages from the mitochondrial electron transport chain, thereby serving as a safeguard for tumor survival by preventing ROS production under hypoxic stress.

Glycogen, another important component of glucose metabolism, forms a reserve energy that can be quickly mobilized to a situation of energy need [49]. Pescador et al. showed that incubation in hypoxia $\left(1 \% \mathrm{O}_{2}\right)$ promoted a glycogen accumulation in mouse myotubes, 
Fig. 1. Reprogramming of the carbohydrate metabolism in tumor cells under hypoxia. Loss of RAS and VHL and PI3K/AKT activation increases HIF1 $\alpha$ expression. HIF1 $\alpha$, in turn, stops the tricarboxylic acid cycle and stimulates LDH, glucose and glutamine uptake, glycolysis, and pentose phosphate pathway. Ac-CoA-AcetylCoenzyme A; ASCT2-ASC aminoacid transporter 2; ASP-Asparate; CIT-Citrate; $\quad$ Fru-1,6- $\mathrm{P}_{2}$-Frutose-1,6-biphosphate; Fru-2,6- $\mathrm{P}_{2}-$ Frutose-2,6- biphosphate; Fru-6-PFrutose-6-Phosphate; FUM-Fumarate; G6PD-Glucose-6-phosphate dehydrogenase; GLS-Glutaminase; Glu-6-P-Glucose-6-phosphate; HIF$1 \alpha$-Hypoxia-induced factor alpha; HK- Hexokinase; LAT1-Amino acid transporter 1; LDHA-lactate dehy-

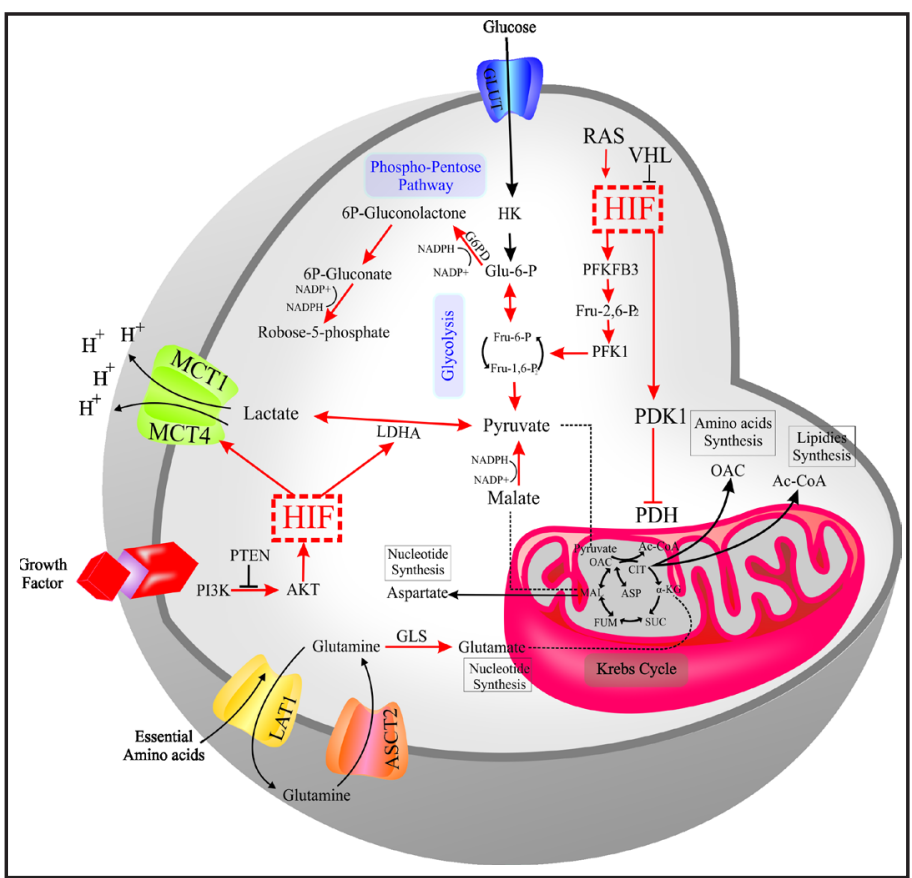
drogenase A; MAL-Malate; MCT1-Monocarboxylate transporter 1; MCT4-Monocarboxylate transporter 4; OAC-Oxaloacetate; PDH—pyruvate dehydrogenase; PDK1—Pyruvate dehydrogenase kinase 1; PFK1— 6-phosphofructokinase 1; PFKFB3-6-phosphofructo-2-kinase/ fructose-2,6-biphosphatase 3; PI3Kphosphoinositide 3-kinase; PTEN-Phosphatase and tensin homologue; SUC-Succinate; VHL-von Hippel-Lindau; $\alpha \mathrm{KG}-\alpha$-Ketoglutarate.

hepatocytes, and hepatoma cells [50]. These authors demonstrated that glycogen synthase 1 (GYS1), through HIF-1, together with upregulation of UTP enzymes (glucose-1-phosphate uridylyltransferase (UGP2) and 1,4- $\alpha$ glucan branching (GBE1) was related to hypoxiainduced glycogen metabolism [50]. Thus, this energy reserve can be accessed by tumor cells in situations of nutritional deprivation. Shen et al. exposed human MCF-7 cells to 24 or $48 \mathrm{~h}$ of hypoxia incubation $\left(1 \% \mathrm{O}_{2}\right)$ [51]. They found that the protein phosphatase 1 regulatory subunit 3C gene (PPP1R3C), also regulated by HIF- 1, allows glycogen accumulation through activation of glycogen synthase, and a limitation of glycogen breakdown through reduction in glycogen phosphorylase activity [51]. Pelletier and collaborators (2012) demonstrated that mRNA and protein levels of the first enzyme of glycogenesis, phosphoglucomutase 1 (PGM1), were increased in many lineages of cancer cells (human colon carcinoma LS174, human breast carcinoma MCF-7 and MDA-MB231, and human renal clear cell carcinoma RCC4 cells) under hypoxia [52].

While hypoxia regulates glycolytic flux in various tumors, glycolytic influence on hypoxic components was demonstrated by Liu et al., who cultured two pancreatic cancer lines under hypoxic conditions $(6 \mathrm{~h})$ in media with different glucose concentrations and $1 \% \mathrm{O}_{2}[53]$. One lineage was HIF- $1 \alpha$ inhibited and other expressed the transcription factor only in hypoxia. The authors found that glucose excess (16.7-22.2 mM) stimulated HIF-1 $\alpha$ production in hypoxia-sensitive lineages [53]. However, in a previous study with the same lineage (adenocarcinoma cell line Mia PaCa-2), Kwon and Lee (2005) noted that HIF-1 $\alpha$ expression was increased in hypoglycemic conditions but not in hyperglycemic conditions ( $8 \mathrm{~h}$ under hypoxia and $0.1 \% \mathrm{O}_{2}$ ) [54]. As indicated by the first author, the time of hypoxia exposition and oxygen concentrations were different, which may have influenced HIF-1 $\alpha$ expression, reaffirming the results [54].

Just as with the Warburg effect, the Pasteur effect was promoted to ensure a favorable metabolic reprogramming of tumor progression. The Pasteur effect represents the increase of glycolytic flux in response to negative feedback caused by allosteric effectors (glucose- 
6-phosphate (Glu-6-P), citrate, and ATP) over key glycolytic enzymes. This results in acceleration of glycolytic flux when the OXPHOS rate decreases, and, inversely, improving the link between glycolysis and OXPHOS fluxes when oxygen levels increase. In nascent tumors, cells distant of vascular supply must choose between hypoxic death and metabolic reprogramming. Due to the rapid need in ATP, the Pasteur effect is inhibited in these cells, but prolonged maintenance energy, mainly for more aggressive tumors, requires further adaptations to accelerate the glycolytic flux [55-57].

In lung cancer cells (A549), Zhang et al. observed that the uptake of fluorodeoxyglucose (F-FDG), a glucose analogue, is increased in regions stained with pimonidazole, and is stimulated by nutritional deprivation, showing that metabolic utilization of glucose is higher in hypoxic and staring regions [58]. The Warburg and Pasteur effects were observed in diverse melanoma cells lines. Scott et al. showed that hypoxic conditions increased the fermentation of glucose into lactate, not only in melanoma cells, but also in melanocytes, emphasizing the importance of hypoxia to metabolic cell rewiring [56].

Even though oxidative phosphorylation is more productive compared to glycolysis, the truth is that local availability of oxygen determines the majority of ATP synthesis of cells in the tumor microenvironment. However, molecular disorders caused by hypoxia affect not only specific points of the reactions responsible for the carbohydrates degradation and energy production. Formation of the glycidic portion in glycoconjugates, glycosylation, is affected by hypoxia both on surface and inside the tumor cells.

\section{Hypoxia Regulates Glycosyltransferases, Glycosidases and Nucleotide Sugar Transporters Expression and Activity}

Glycosylation is a phenomenon of molecular modification, in which the connections that leads to glycoconjugates are made and unmade by glycosyltransferases and glycosidases. Glycosyltransferases represent a very large family of enzymes that determine the biosynthesis of glycans by group-transfer reaction. In this reaction, the monosaccharide moiety of a simple nucleotide sugar donor substrate, such as UDP-Gal (Uridine diphosphate galactose), GDP-Fuc (Guanosine 5'-diphospho-fucose), or CMP-Sia (Cytidine 5'-monophospho-Nacetylneuraminic acid), is transferred to the acceptor substrate that includes oligosaccharides, monosaccharides, polypeptides, lipids, small organic molecules, and even DNA [59]. These enzymes, not only act in intracellular medium, but they also contribute to the glycosylation of cell surface receptors and extracellular matrix components, modulating signaling pathways and tumor behavior $[60,61]$.

Modifications in glycosyltransferase and/or glycosidase expression, activity, and structure play a key role in the onset and progression of cancer, epithelial-mesenchymal transition (EMT), and metastasis [62-64]. These changes cause concomitant reconfiguration of the "glycocode" of tumor cells through fundamental processes in glycosylation, such as $\mathrm{N}$ - and O-glycosylation.

In cancer, glycosylation patterns can be altered by many factors, including changes in the expression levels of glycosidases and glycosyltransferases genes. This is due to loss of heterozygosity, a promoter methylation, and increase of gene expression or neoexpression [65-67]. Hypoxic microenvironments change the expression of glycosyltransferase genes, such as fucosyltransferases (FUTs), $N$-acetylglucosaminyltransferases (GnTs), and sialyltransferases (STs) [68-70]. The induction of a number of glycosyltransferase expressions by hypoxia induces tumor progression in various types of cancer, including colon, bile duct, bladder, gastric, and lung [68-73], as well as glycosidase gene expression $[61,74-76]$.

The Mgat5 (mannosylglycoprotein N-acetyl-glucosaminyltransferase 5) gene encodes GnT-V, an enzyme that catalyzes the transfer of N-acetylglucosamine (GlcNAc) to $\alpha 1,6$ mannose in $\mathrm{N}$-glycans to form a $\beta 1,6$-branched $\mathrm{N}$-glycan, thus elongating the polylactosamine structure. This molecule controls cell surface receptor position and is associated with some of the invasive characteristics of tumors [77-79]. GnT-V is regulated by Ets-1, a member 
Fig. 2. Indirect induction of Gnt-V expression by HIF-1. Activation of Mgat5 via Ets-1 and polylactosamine elongation by addition of $\mathrm{N}$-acetylglucosamine. Gnt-V is responsible for polylactosamine structure, which is associated with some of the invasive characteristics of tumors. Gnt-V: $\mathrm{N}$-acetylglucosaminyltransferase V; HIF- $1 \alpha$ : hypoxia inducible factor 1 alfa; Ets-1: E-twenty six 1; Asn: asparagine; UDP: uridine diphosphate.

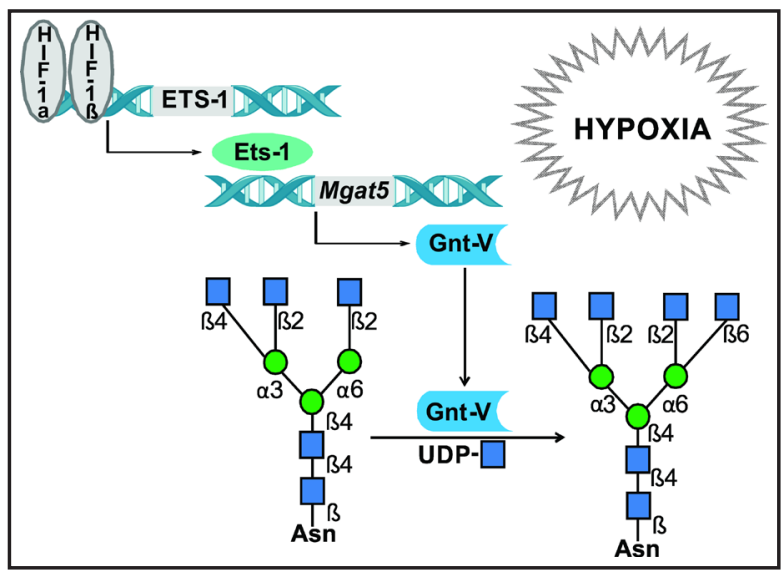

of the E-twenty-six (Ets) family of transcription factors, in various cancer cell lines. The expression of the Ets-1 gene is induced in hypoxia conditions via HIF-1 $\alpha$ (Fig. 2), suggesting that hypoxia indirectly induces GnT-V expression [71-73].

Croci et al. reported that hypoxia also influences endothelial cell (EC) receptor glycosylation by increasing the amounts of $\beta 1-6 \mathrm{GlcNAc}$-branched N-glycans and polyLacNAc (N-acetyllactosamine) structures [70]. Hypoxia also reduces $\alpha 2-6$ sialylation and induces slight changes in asialo-core-1 0-glycans, an epitope specific to galectin-1 (Gal-1) conferring resistance to treatment with anti-VEGF (Vascular Endothelial Growth Factor) across several types of cancers, including metastatic breast cancer, metastatic colorectal cancer, non-small-cell lung cancer, renal cell carcinoma, and hepatocarcinoma [70]. Core2 ß1-6-N-acetylglucosaminyltransferase 1 (C2GNT1) is responsible for changes in the 0 -glycosylation process, acting on asialo-galactose- $\beta 1-3-\mathrm{N}$-acetylgalactosamine core 1 0 -glycans to synthesize the core 2 branching structure. This alteration provides higher binding of Gal-1 to ECs, cultured under hypoxic conditions, ensuring tumors angiogenesis. Croci and collaborators (2014) also observed that Mgat5 silencing prevented EC proliferation, migration, and tube formation induced by Gal-1 in a hypoxic microenvironment [70]. These changes in EC glycome, mainly in Vascular Endothelial Growth Factor Receptors (VEGFRs), could to remodel the EC surface glycome selective to specific endogenous lectins. This process translates glycan-containing information into functional cellular responses [80], promoting tumor-immune escape and metastasis [81-83].

A study demonstrated that HIF- $1 \alpha$ negatively regulated the fucosyltranferase expression (FUT1 and FUT2) in pancreatic cancer cell lines, resulting in low expression of fucosylated glycans on the cell surface [84]. These enzymes catalyze the addition of fucose to the galactose residues in Gal $\beta 1-3 \mathrm{GlcNAc}-\mathrm{R}$ and Gal $\beta 1-4 \mathrm{GlcNAc}-\mathrm{R}$ glycans to produce $\mathrm{H}$ type 1 and 2 antigens, respectively, precursor structures of the Blood Group A and B antigens. The reduction of $\alpha 1,2$-fucosylation results in low $\mathrm{H}$-antigen levels, and, thereafter, in low levels of BG antigens, which has been associated with increased cellular motility and resistance to apoptosis [84]. However, prostate cells (RWPE1) cultured in acute hypoxia demonstrated significant upregulation of FUT1, GCNT2, and GCNT3 (Polylactosamine Branching N-Acetylglucosaminyltransferases 2 and 3), which are required for prostate cancer lipid antigen (PCLA) synthesis [69]. PCLA is a glycolipid that is restricted to the prostate cancer cell surface, specifically recognized by monoclonal antibody (mAb) F77. mAb F77 is an antibody produced by immunizing mice with the prostate cancer cells line PC-3, which directly promotes cell death, showing potential for diagnosis and therapy [85]. These studies show that the hypoxic modulation is tumor-dependent, and that each tumor cell has a different behavior.

In colon cancer (SW480), the expressions of FUT7, ST3Gal1 ( $\beta$-galactoside $\alpha$-2,3sialytransferase), and UDP-Gal transporter were induced by hypoxia [84]. FUT7 and ST3GAL1 attach fucose in $\alpha 1-3$ linkage to LacNAc moieties, and catalyze the transfer of $\mathrm{N}$-Acetylneuraminic acid in $\alpha 2-3$ on Gal residues, respectively [86, 87]. These enzymes 
Fig. 3. NEU4S downregulation induced by hypoxia in colon cancer cells. Under normal conditions, NEU4S removes sialic acids and lower the binding of cancer cells to E-selectin on EC. However, in a hypoxic microenvironment, NEU4S downregulation induces the expression of sialyl-Lewis antigens and the binding of cancer cells to E-selectin, causing an increase of malignancy. Ser: serine; Thr: threonine; EC: endothelial cell; HIF- $1 \alpha$ : hypoxia inducible factor 1 alfa; NEU4S: human sialidase type; FUT7: fucosyltransferase 7; ST3GAL1: $\beta$-galactoside $\alpha$-2,3-sialytransferase.

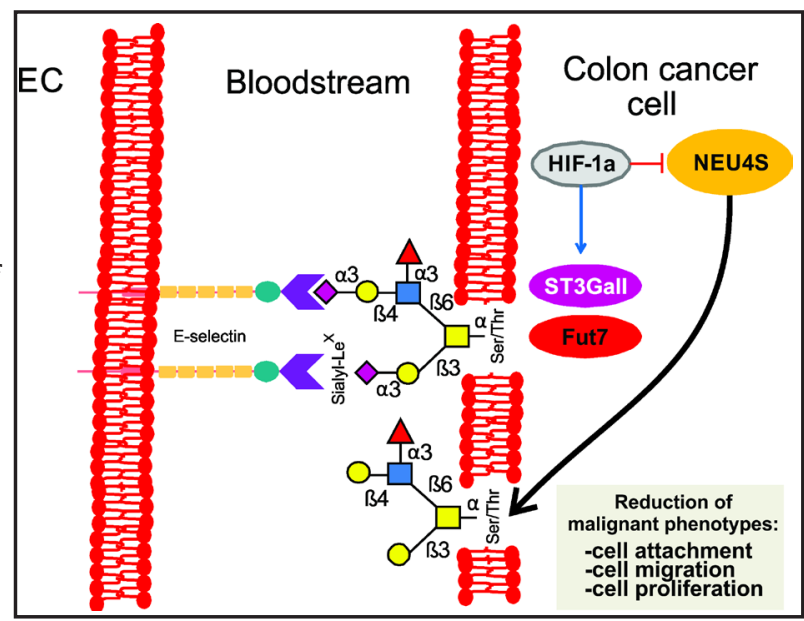

are involved in the synthesis of pro-tumor antigens sialyl Lewis $\mathrm{x}\left(\right.$ sialyl-Le $\left.{ }^{\mathrm{x}}\right)$ and sialyl Lewis a (sialyl-Le $\left.{ }^{\mathrm{a}}\right)$, carbohydrate ligands of endothelial E-selectin, which contributes to hematogenous metastasis [84]. Sialyl-Le ${ }^{\mathrm{x}}$ and its isomer, sialyl-Le ${ }^{\mathrm{a}}$, are tetrassacharide structures and fucosylated antigens terminated by $\alpha 2-3$-sialic acid linked to the galactose residues [88]. Koike et al. observed that SW480 colon cancer cells have increased sialyl$\mathrm{Le}^{\mathrm{x} / \mathrm{a}}$ levels after seven days under hypoxic conditions [68]. Results were similar for cultures induced in a hypoxia chamber $\left(1 \% \mathrm{O}_{2}\right)$, and also using hypoxia mimetic desferoxamine. Under hypoxic conditions, cells also presented an enhancement of cell adhesion to endothelial E-selectin. In SW480 cells transfected with dominant-negative form of HIF, it was observed that there was a less pronounced increase of sialyl-Le ${ }^{a / x}$ levels, indicating that HIF is directly involved in the induction process. After restoration of oxygen levels, the expression of sialyl Lewis a and $\mathrm{x}$ returned to basal levels [68].

Glycosidases also participate in glycosylation reactions, removing monosaccharides to form intermediates, especially in the formation of $\mathrm{N}$-glycans [87]. Aberrant sialylation is a characteristic feature of cancer cells, and has been proposed to be associated with malignant phenotypes, including invasiveness and metastatic potential [88].

In a hypoxic tumor microenvironment, sialyl-Le expression was up-regulated, accompanied by elevation of ST3Gal1 and FUT7. Shiozaki et al. found that hypoxia mimetic deferoxamine was capable to promote downregulation of NEU4S (a Human Sialidase Type) in HCT-15 colon cancer cells, which in turn favors ST3Gal1 activity to increase in sialyl-Le levels [76]. Hypoxia-induced sialyl-Le ${ }^{\mathrm{x}}$ upregulation in SW-480 cells was also associated with the reduction of mRNA levels of NEU4S [76]. NEU4S catalyzes the removal of sialic acids, causing a reduction of cell attachment, cell migration, and cell proliferation, probably by lowering the binding of cancer cells to E-selectin in EC [60]. Therefore, NEU4S downregulation induced by hypoxia favors sialyl-Le ${ }^{a / x}$ antigens upregulation, increasing a malignant phenotype (Fig. 3).

Heparanase (Hpa) activity and expression level significantly increased after exposure to hypoxia in pancreatic MIA PaCa-2 cancer cells, human ovarian cancer cell line (OC-MZ-6), and Hep-2 laryngeal carcinoma cell line $[61,74,75]$. This endo- $\beta$-glucuronidase catalyzes the cleavage of heparan sulfate (HS) side-chains, enhancing tumor cell invasion and migration, and releasing important HS-binding cytokines, relevant to angiogenesis, wound healing, and tumor growth [62]. The transfection of the Hpa gene into poorly metastatic cell lines is associated with a significant increase in metastasis in vivo, and clinical studies have correlated increased Hpa activity with invasion and poor prognosis [89-91].

Studies have demonstrated that hyaluronic acid (HA), a polysaccharide component of the vessel basal membrane, is involved in the angiogenesis process [92]. The enzyme hyaluronidase (HAase) in lysosomes is responsible for HA degradation, digesting high molecular weight HA into low molecular weight HA (SMW) [93]. Chemical inducers of hypoxia $\left(\mathrm{CoCl}_{2}\right.$ and $\left.\mathrm{NaN}_{3}\right)$ can upregulate the production of $\mathrm{HA}$ and HAase activity, resulting in a significant increase of SMW expression in T47D human breast cancer cells. Since SMW 
Table 1. Effects of hypoxia on glycosyltransferases, glycosides and nucleotide sugar transporters and their functional consequences per cancer type

\begin{tabular}{|c|c|c|c|}
\hline Cancer Type & Hypoxic modulation & Malignant Features & REF \\
\hline $\begin{array}{l}\text { Gastric, lung, pancreatic mammary, } \\
\text { hepatic, glioblastoma, melanoma }\end{array}$ & GNT-V (indirect induction) & Angiogenesis & {$[71-73]$} \\
\hline Prostate & $\begin{array}{l}\text { Up-regulation of FUT1, GCNT2 and } \\
\text { GNCT3 }\end{array}$ & Immune evasion & [69] \\
\hline Colon & $\begin{array}{l}\text { Overexpression of FUT7, ST3GAL1 } \\
\text { and UDP-GAL transporter }\end{array}$ & Metastasis & {$[68]$} \\
\hline Colon & $\begin{array}{l}\text { Up-regulation of ST3Gal1 and FUT7 } \\
\text { and NEU4S down-regulation }\end{array}$ & $\begin{array}{l}\text { Adhesion migration } \\
\text { and proliferation }\end{array}$ & {$[60,76]$} \\
\hline $\begin{array}{l}\text { Pancreatic, ovarian, laryngeal } \\
\text { cancers }\end{array}$ & $\begin{array}{l}\text { Increase of Hpa expression and } \\
\text { activity }\end{array}$ & $\begin{array}{l}\text { Metastasis and } \\
\text { invasion }\end{array}$ & $\begin{array}{l}{[61,74,75,89} \\
91]\end{array}$ \\
\hline Breast cancer & Increase of HAse activity & Angiogenesis & [92] \\
\hline
\end{tabular}

presents pro-angiogenic properties, results indicate that hypoxia may promote angiogenesis [94].

Hypoxia regulates glycosyltransferases and glycosidases expression in epithelial tumors, such as colon, pancreas, ovary, breast, prostate, and laryngeal carcinomas (Table 1). There are few reports regarding the influence of a hypoxic microenvironment in nucleotide sugar transporters expression. Further studies are necessary to understand the role of these molecules in tumors exposed to hypoxic conditions, since they play an important role in the glycosylation reaction.

\section{Hypoxia Changes Membrane Glycoconjugates in Tumor Cells}

The hypoxia microenvironment can affect the expression of different types of glycoconjugates, such as glycoproteins and glycolipids [68, 95, 96]. Some studies have reported molecular changes promoted by the hypoxia microenvironment, but did not elucidate the functional consequences promoted by glycoconjugates alterations in neoplastic cells. However, some studies associated these modifications with cancer cell proliferation, migration, and survival, indicating that such glycoconjugates may be used as targets for further therapeutic strategies for cancer treatment [97-99].

\section{Glycoproteins}

Hypoxia can modulate the expression of various cell membrane glycoproteins. Among these we can highlight the Carbonic Anhydrase IX (CAIX) which play a central role in neoplastic cells adaptation to hypoxic microenvironment and mucins and integrins that are related to invasion and migration. HIF- $1 \alpha$ can regulate the expression of CAIX, an $N$-linked transmembrane glycoprotein that is increased in malignant cells, including breast cancer $[100,101]$. Ivanov and collaborators (2001), observed, using immunochemistry, the increased expression of CAIX in hypoxic regions of melanoma and breast carcinomas (Fig. 4) [102]. CAIX mRNA levels are also increased under hypoxic conditions in U87 glioblastoma cells [102]. In 2011, Li and collaborators observed that hypoxia promoted a significant increase of CAIX expression and activity in breast cancer cells (MDA-MB-231) [101]. Results of endoglycosidase $\mathrm{H}$ digestion assay showed that CAIX is present as a dimeric, high-mannose $\mathrm{N}$-glycosylated protein. Such a structure is common in various types of cancer; however, it is atypical in normal cells [101]. Despite the current data, there are no studies that directly related the changes in CAIX glycosylation pattern promoted by hypoxia.

$\mathrm{N}$-glycosylation is a well-characterized type of protein glycosylation and represents a vital process [103]. The N-glycosylation process follows coordinated steps that occur along the endoplasmic reticulum (ER) to Golgi, and its physiological functions include cellular mechanisms involved in cell-cell adhesion, cell motility, signal transduction, and hostpathogen recognition $[3,62,104]$. Changes in the $\mathrm{N}$-glycosylation process can be related to oncogenesis and cancer progression. In fact, these structural changes are important in understanding the implications of the adhesive properties of cancer cells $[105,106]$. 
Fig. 4. Regulation of N-glycosylation promoted by intratumoral hypoxia. The hypoxic microenvironment alters cell glycosylation by modifying enzymes involved in the process. Increase of hypoxia-inducible factor alpha (HIF-1 $\alpha$ ) leads to an indirect reduction of intracellular levels of uridine diphosphate $\mathrm{N}$-acetylglucosamine (UDP-GlcNAc), a substrate for $\mathrm{N}$-glycosylation. HIF- $\alpha$ also induces the reduction of fucosyltransferases FUT1 and FUT2. HIF- $1 \alpha$ also regulates the expression of carbonic anhydrase IX (CAIX), an N-linked transmembrane glycoprotein present in malignant cells. A hypoxic microenvironment also prevents efficient glycosylation, blocking the expression of $\alpha 3$ ITGA in the plasma membrane.

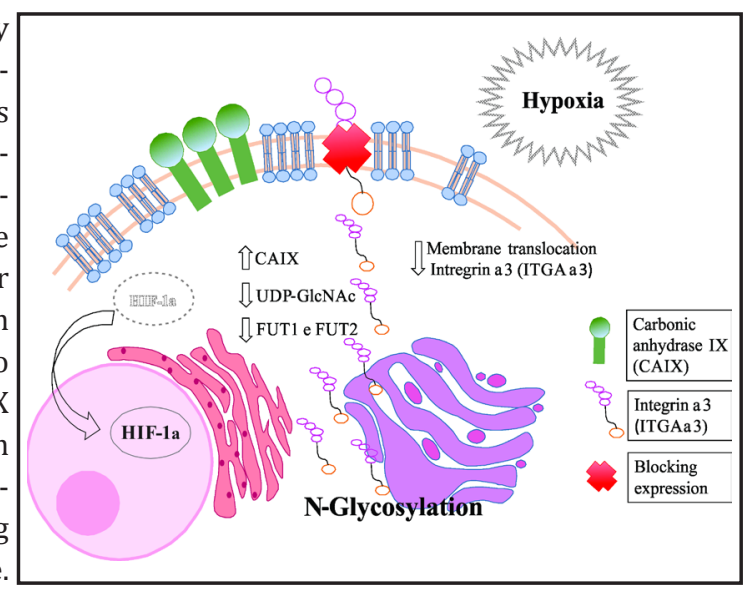

A study performed by Ren et al. evaluated the effect of hypoxia on the integrin family in A431 epidermoid carcinoma cells [97]. Expressed glycoproteins were identified and quantified by iTRAQ (isobaric tags for relative and absolute quantitation) and liquid chromatography-mass spectrometry analysis. This author observed changes in integrin $\alpha-3$ (ITGA3) levels, and its $N$-glycosylation, were inhibited by hypoxia. Other techniques (Western blotting, flow cytometry, immunofluorescence, and immunoprecipitation assays) showed that changes induced by hypoxia prevented ITGA3's efficient translocation to the plasma membrane. Mutagenesis studies indicated that lower levels of ITGA3 on the cell surface, such as hypoxia-induced levels, increase the invasiveness potential of cancer cells in vitro by blocking ITGA3's interaction with extracellular ligands (Fig. 4) [97].

As in N-glycosylation, modifications in O-linked glycosylation are usual characteristics of malignant transformation in epithelial cells [98]. O-linked glycosylation is one of the most common post-translational mechanisms by which glycans are covalently linked to serine/ threonine residues $[107,108]$. This process can occur in the Golgi, in the ER, or in the cytoplasm/nucleus $[109,110]$. 0-glycans are often classified as mucins and non-mucins.

Mucin type $\mathrm{O}$-glycosylation is initiated by the $\alpha$-linkage of $\mathrm{N}$-acetylgalactosamine (GalNAc) moiety to the hydroxyl group of serine or threonine [110]. Formation of this c556omplex is catalyzed by GalNAc transferases, and the core $\alpha$-GalNAc-Ser/Thr is called Tn antigen [111]. Subsequently, several glycosyltransferases are responsible for the elongation and termination of O-linked glycans, which usually includes galactose, GlcNAc, GalNAc, fucose, or sialic acid. Non-mucin 0 -glycans include $\alpha$-attached via 0 -mannose, $\alpha$-linked 0 -fucose, and the $\beta$-linked $\mathrm{N}$-acetylglucosamine (0-GlcNAc) [112]. Small or truncated O-glycans are increased in different types of tumors, including gastric, colon, breast, and pancreatic cancer $[113,114]$, and their production is associated with a poor prognosis and metastasis [115].

Mucins constitute a family of glycoconjugates that are involved in epithelial cell homeostasis. Thus far, 21 mucins have been identified and can be found in membrane-bound or secreted forms [82]. Altered expression of mucins has been reported in several types of tumors, including gastrointestinal and breast cancer [116, 117], and they have also been associated with hypoxic microenvironments.

Mucin 1 (MUC1) is a type I transmembrane protein, overexpressed in several cancer types, including pancreatic adenocarcinoma, and there is a known relationship between this protein and hypoxia. MUC1 regulates cancer cell metabolism, occupying the promoter elements of multiple genes involved in glucose metabolism in pancreatic cancer cells and stabilizes HIF-1 $\alpha$ [99]. In contrast, in HTC116 colon cancer cells, MUC1 blocks hypoxiainduced stabilization of HIF- $1 \alpha$ and consequently suppress ROS and hypoxia-induced apoptosis [118]. In human lung adenocarcinoma cell line, hypoxia increased MUC1 mRNA and protein levels via HIF-1 $\alpha$ [94]. A similar pattern was shown in clear renal cell carcinomas. MUC1 is overexpressed in these renal carcinomas and a concomitant increase of MUC1 and 
Fig. 5. Modifications in glycoconjugates patterns promoted by hypoxia in cancer cells and their functional consequences (HIF-1 $\alpha$ : Hypoxia-Inducible Factor 1-Apha; MUC: Mucin; VEGF-A: Vascular Endothelial Growth Factor A; PDGFB: Platelet-Derived Growth Factor Subunit B; CTGF: Connective-Tissue Growth Factor; NeuGc: $N$-glycolyl sialic acid; GM2: ganglioside monosialic 2).

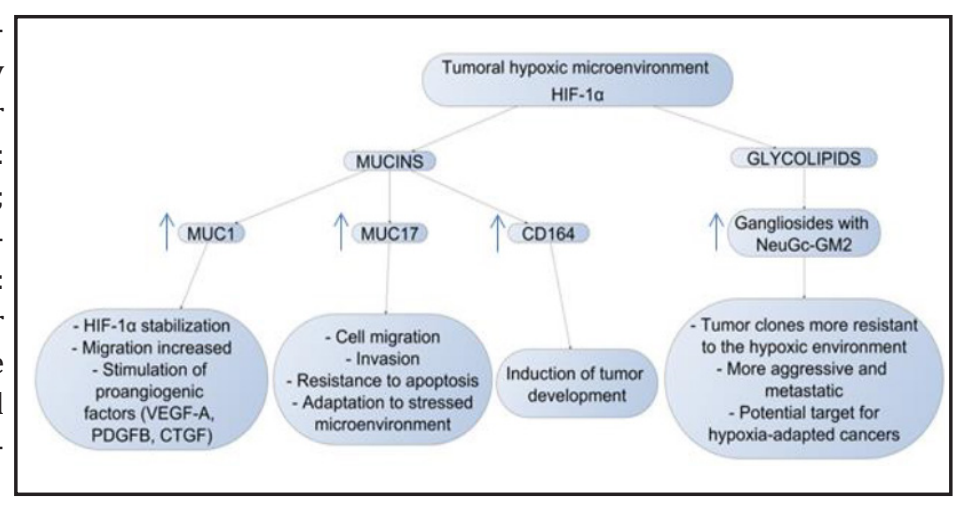

HIF1- $\alpha$ in metastatic groups was observed. Furthermore, MUC1 expression under hypoxia is regulated by a HIF1- $\alpha$-dependent mechanism, having effects on the migration properties of renal cancer cells [119]. MUC1 also participates in angiogenesis in AsPC1 pancreatic cancer cells. It has been shown that MUC1 is overexpressed in hypoxic conditions and stimulates proangiogenic factors VEGFA, PDGFB (Platelet Derived Growth Factor Subunit B), and CTGF (Connective Tissue Growth Factor) (Fig. 5) [120].

Other glycoproteins of the mucin family also present changes mediated by hypoxic conditions. Mucin 17 (MUC17) is a type I membrane-bound mucin that, under physiological conditions, plays an important role in colon-mucosal protection and cell restitution processes. MUC17 upregulation is associated with poor overall survival in pancreatic ductal adenocarcinoma [121]. Kitamoto et al. showed that MUC17 is significantly induced by hypoxia in a time-dependent manner in human pancreatic cancer cell lines (AsPC1 and HPAFII), and the induction is mediated by HIF1- $\alpha$ [122]. Since silencing of MUC17 gene in colon cancer cells was associated with reduced cell aggregation, cell-cell adherence, migration, and increased susceptibility to apoptosis [123], MUC17 overexpression may be involved in cancer cell progression (Fig. 5).

CD164 (or endolyn) is a type I integral transmembrane sialomucin that acts as a signaling receptor that regulates proliferation, adhesion, and migration in hematopoietic stem cells. This glycoprotein is also involved in the development of skeletal muscle [124]. In the tumor context, CD164 participates in the development of colorectal cancer and metastasis of prostate cancer cells to bone marrow. Tang et al. showed that hypoxia might be one factor responsible for CD164 upregulation in HCT 116 colorectal carcinoma cells, inducing tumor development (Fig. 5) [125].

\section{Glycolipids}

Such asglycoproteins, glycolipidsalso change during malignant transformation, and these changes seem to be involved in the molecular mechanisms needed for early and late stages of carcinogenesis [126-128]. These changes are also affected by hypoxia, as demonstrated by Tanaka et al. in human colorectal cancer cells (Caco-2) under hypoxic conditions $\left(\mathrm{O}_{2} 1 \%\right)$ for three days [129]. The authors showed that, in normoxia, major constituent ceramide species of neutral glycosphingolipids (NGSLs) were composed of the usual long-chain base of sphingosine (d18:1) and hydroxy fatty acid (HFA); while, under hypoxic conditions, all the Cers, and nearly $80 \%$ of the sphingomyelins, were dihydrosphingolipids, composed of d18:0-NFAs, but a significant proportion of d18:1-HFAs still remained in the NGSLs [129].

Gangliosides are acid glycosphingolipids that carry one or more residues of sialic acid, and are more abundant in the brain $[127,130]$. Sialin, a gene for sialic acid transporter, is upregulated in colon cancer CaCo-2M cells and breast cancer ZR-75-1 cells submitted to hypoxic conditions, and is related to enhanced gangliosides carrying N-glycolyl sialic acid (NeuGc) [131]. Upregulation of sialin in hypoxic culture promotes the expression of NeuGc-GM2 (Ganglioside Monosialic 2) through an increase in the transport speed of sialic acid from external medium to cancer associated-ganglioside GM2. This results in a 
significant accumulation of unusual gangliosides carrying N-glycolyl sialic acid in cancers. Such gangliosides serve as surrogate markers for the presence of cell masses suffering from chronic hypoxia (Fig. 5) [131].

Cytidine Monophospho-N-Acetylneuraminic Acid (CMP-NeuAc)-hydroxylase oxidase is present in many mammals, but absent in humans, and is the enzyme responsible for de novo synthesis of N-glycolyl sialic acid through oxidative hydroxylation of $\mathrm{N}$-acetyl sialic acid [128, 132]. Because it is an oxidative hydroxylation, this process, and the concomitant production of NeuGc through de novo synthesis, may be suppressed in hypoxic tissues in mammals that express CMP-NeuAc-hydroxylase. In contrast, the expression of NeuGc increases under hypoxic conditions in humans, where its level is determined by its salvaging through the transporter Sialin, instead of de novo synthesis [128].

Another glycolipid is gangliotetraosylceramide (Gg4), which has important role in EMT process inhibition in human and mouse epithelial cells lines [133]. Pre-incubation with Gg4 can block the EMT process due to the strong linking capacity of Gg4 to E-cadherin and $\beta$-catenin, as evidenced by Guan et al. through immunoprecipitation. Under hypoxic conditions, normal murine mammary gland (NMuMG) showed reduced levels of Gg4, indicating a possible trend to EMT [134].

Ganglioside GD3 has important role in the cell proapoptotic pathway, and it is known that GD3 reduces nuclear factor-kappa B (NF- $\kappa \beta$ ) levels, a molecule involved in the establishment of hypoxia [135-137]. Overexpression of GD3 synthase in human hepatocarcinoma cell line Hep3B sensitizes this cell line via hypoxia-induced ROS generation through its ability to suppress the tyrosine kinase cSrc/NF-kB survival pathway [138], emerging as a therapeutic strategy to be studied. Hypoxic incubation of human colon cancer cell line LS174T promoted induction of GD3 expression and moderate induction of GM3.

Another factor that supports the use of gangliosides as therapeutic targets are the clinical successes recently achieved. The anti-idiotype vaccine targeting the NeuGcGM3 tumorassociated ganglioside in patients with advanced non-small cell lung cancer has proved to be effective and a well-tolerated treatment option [139]. Furthermore, FDA recently approved an antibody against disialoganglioside GD2 (dinutuximab) for neuroblastoma treatment [140]. However further studies are needed to evaluate the effects of these therapies in hypoxic microenvironment.

Increasing evidence about the functional role of glycolipids in a significant number of cellular physiological pathways has been consolidating the hypothesis that glycolipids participates on establishment of malignant cell behavior in hypoxia. Therefore, these glycoconjugates have a higher possible potential to serve as molecular therapeutic targets and clinical predictors in cancer.

Sialyl-Le ${ }^{\mathrm{x} / \mathrm{a}}$, which are expressed either protein- or lipid-bound on the cell surface, have their expression increased in different types of cancer, including gastric, colorectal, oral squamous cell, and pancreatic cancer [141-144]. During the metastasis process, they act as carbohydrate ligands for E-selectin-mediated cancer cell adhesion [145]. Sialyl-Le a and Sialyl-Le $\mathrm{x}^{\mathrm{x}}$ are found in CA19-9 and NCC-ST-439 clinical markers, respectively, and are used for monitoring cancer recurrence after surgery, especially for pancreatic and gastric cancers $[11,146]$. The induction of sialyl-Le ${ }^{\mathrm{a} / \mathrm{x}}$ is caused by alteration of glycosyltransferases and sugar transporter gene expression, which may be mediated by hypoxic conditions [76].

As far as we know, there are no studies that associated other Tumor-Associated Carbohydrate Antigens (TACA), such as T, Tn, and Lewis b/y antigens, to intratumoral hypoxia.

\section{Alterations in the Cell-Cell and Cell-Extracellular Matrix Interactions Under Hypoxia}

Proteoglycans (PGs) are macromolecules composed of a core protein chain with one or more glycosaminoglycan (GAGs) covalently attached to the protein structure. GAGs are polysaccharides formed by repetitions of negatively charged disaccharides. They are usually

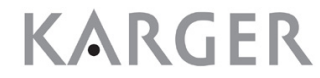


categorized in groups: Chondroitin sulfates (CSPG), keratan sulfates (KSPG), dermatan sulfates (DSPG), heparan sulfates (HSPG), and hyaluronic acid (HA) [147].

Regarding to PGs' location, when they are produced intracellularly can be kept in secretory vesicles to regulate the viability of certain enzymes. They can be inserted into the plasma membrane to interact with receptors and ligands, inside or outside the cell, such as syndecans and glypicans. Finally, they can be released into the extracellular matrix (ECM), among which may be mentioned perlecans, biglycans, aggrecans and decorins $[148,149]$. The variety of GAGs that may be attached to PGs confers a molecular complexity, which directly reflects possible interactions that these macromolecules can participate in.

Among CSPGs, there are small leucine-rich proteoglycans (SLRPs), which are composed primarily of leucine-rich repeats. They are significantly present in ECM and are capable of stabilizing collagen fibers and promoting cellular growth, apoptosis, and tissue remodeling [150]. Neurocan is an SLRP expressed in the central nervous system during the late embryonic phase. This PG participates in a critical step of this system's development, controlling neuronal growth through inhibition of neurite outgrowth [151]. Perlecan, agrin, and collagen type XVIII are examples of some PGs with structural functions at the basement membrane, an organized layer of the ECM [152-154].

Syndecan family members are intramembranous and have a cytoplasmic tail, participating in signal transmission from the extracellular environment to the cytoplasm $[155,156]$. Heparan sulfate is closely associated to the differentiation process of stem cells; embryonic stem cells derived from knockout mice of EXT1 (exostosin glycosyltransferase 1), a gene responsible for HSPG synthesis, did not differentiate, except when it was post-treated with heparin [157]. Others types of PGs have essential roles in the specific tissues in which they are localized, but their functions are related to crucial processes, such as homeostasis, development, repair, and disease, especially in tumor conditions [147] .

Cancer cells, through different cell-cell and cell-ECM interactions, promote alterations in the tumor microenvironment in order to favor proliferation, development, and potential invasion of distant tissues $[158,159]$. Among modifications in ECM composition, the majority occurs through PGs glycosylation, either enhancing or decreasing the expression of some of these molecules, such as syndecans, or inhibiting the production of others [6,160-162]. The association between hypoxia and tumor progression is also correlated with alterations in ECM composition through HIF-1 $\alpha$ control of the glycosylation process [163-165].

It is known that a hypoxic condition, in the cancer context, promotes the recruitment of macrophages to growing tissue [166-168]. Asplund et al. noticed that hypoxia, combined with enzymatic removal of HSPGs chains, increased the motility of macrophages more than hypoxia per se. Hypoxia reduced the expression of syndecans-1 and -4 , and inhibited the expression of EXT1 and EXT2 enzymes, both known to be tumor suppressor genes and related to HSPG synthesis [169].

Versican, a CSPG from the aggrecan family, is the most common PG in ECM, involved in cell adhesion, proliferation, and migration under healthy conditions [170-172]. It is known that the versican produced by mononuclear cells participates in the process of blood vessel formation, suggesting that this molecule may promote angiogenesis and tumorigenesis [173]. However, in hypoxia, versican has its specific production by macrophages upregulated, even more so after a long exposure (five days) as opposed to only one day [174]. These cells are over-recruited in hypoxic areas, and remain there for long periods of time. Studies involving macrophages and hypoxic conditions showed how tumor cells and their microenvironment could manipulate, directly and indirectly, many different mechanisms to favor its own development and growth.

On the other hand, Koike et al. focused on investigating the possible effects of HIF control on carbohydrate determinants. Human colon cancer cells lines (SW480, C-1, and Colo201 lineages) were used to understand the relationship between PGs and cell-adhesion molecules. The authors reported that hypoxic conditions increased syndecan- 4 and $\alpha 5-$ integrin gene expression. Both macromolecules are involved in cellular migration and celladhesion processes, especially in the enhanced adhesion of cancer cells to fibronectin, which 
is considerably expressed by vascular endothelial cells [84].

Lumican is a member of the SLRP family and can regulate diverse essential processes, such as cell proliferation, adhesion, and invasion, and is critical to control tumor progression and development [175]. Its expression, both positive and negative, has been associated with tumor growth, depending on the tissue [176-179]. In a clinical study, 131 patients with pancreatic ductal adenocarcinoma (PDAC) tumors were selected in order to correlate lumican expression and the tumor progression. Primary PDAC cells and recombinant human lumican protein were used to simulate in vivo interactions between stromal lumican and PDAC cells. The study showed that patients who had PG localized mostly in the stromal rather than the epithelial area also presented a decrease in metastatic recurrence. In vivo model showed that lumican decreased EGFR (epidermal growth factor receptor) and HIF-1 $\alpha$ expression via Akt; cancer cells with enhanced HIF-1 $\alpha$ activity became resistant to lumican-induced inhibition of glucose consumption and apoptosis [180]. Therefore, lumican acts against pancreatic cancer cell development, protecting the microenvironment from the consequences of HIF$1 \alpha$, and is correlated with tumor progression.

Decorin, another PG from the SLRP family, has an important role in ECM protection and in the inhibition of tumor progression, mainly by disfavoring angiogenesis [181, 182]. Neill et al. reported that decorin reduced HIF- $1 \alpha$ in a breast cancer in vitro model (MDAMB-231 lineage), as well as VEGFA, both in normoxic conditions, performing an important role against tumor growth [183]. In the hypoxia context, decorin protected glioblastoma cells, both in vitro and in vivo, against oxygen and glucose deprivation situations. It was observed that an overexpression of p21, p27 (both tumor suppressor genes), and Ras mRNA levels, and induction and activation of Akt at the protein level, were unusual under normoxic conditions [184]. Ras enhancement is directly related to PI3K (Phosphoinositide 3-Kinase) interactions, and, consequently, Akt activation, resulting in protection against apoptosis [185]. Inhibition of hypoxia-induced death suggests that decorin could be essential in increasing the sensitivity of cells for anticancer therapy.

Integrins are a specific type of glycoproteins present on cell surfaces, which can bind to PGs in ECM, with cardinal roles in tumor progression. Under hypoxic conditions in a glioma model (U251 lineage), inhibition of $\alpha v \beta 3$ integrin decreased focal adhesion kinase (FAK) and proline-rich tyrosine kinase 2 (Pyk2) phosphorylation, which are associated with cell migration and invasion [186].

Integrin-linked kinases are usually overexpressed in colorectal cancer patients and are associated with tumor survival and invasion under hypoxic conditions [187]. In human epithelial carcinoma (A431), Ren et al. reported that hypoxia-induced alterations to the glycosylation of ITGA3 prevented its efficient translocation to the plasma membran. This resulted in an enhanced invasive competence to cancer cells [97]. In another indirect correlation between PGs, integrins, and hypoxia, You et al. showed that pericyte expression of NG2 (neuron glia antigen-2) is critical for its interaction with endothelial cells in a NG2 knockdown melanoma (B16F10 lineage) model. Knockdown of NG2 caused several structural deficits in blood vessels in intracranial B16F10 melanomas, and, consequently, intratumoral hypoxia. This event was associated with the loss of $\beta 1$ integrin activation in endothelial cells, suggesting a potential role of NG2 against hypoxia [188].

It was observed that some PGs may inhibit tumor progression, such as decorin, while others have pro-tumor activity, such as versican. Others, such as lumican, depending on the cancer tissue, can promote or delay the development of cancer. HIF- $1 \alpha$ can control some cellular processes through up- or downregulation of PGs and integrins (Fig. 6). For example, HIF- $1 \alpha$ controls cell adhesion, inducing syndecan and integrins expression, favoring metastasis. Since glycomolecules, as lumican, can regulate the expression and activity of HIF-1 $\alpha$, pancreatic cancer cell proliferation was inhibited through HIF-1 $\alpha$ downregulation. Studies concerning hypoxia and alterations in PGs and/or integrins, and the interactions between ECM and cancer cells, in order to understand how they can be used to develop new targets and tools against current resistance to chemotherapies, are still insufficient.

\section{KARGER}


Fig. 6. Modifications of PGs, integrins and HIF$1 \alpha$ expression and activity under hypoxic conditions. ECM: Extracellular matrix; EXT-1 and EXT-2: Genes correlated to heparan sulfate proteoglycan synthesis and tumor suppression; VEGF-A: Vascular endothelial growth factor $\mathrm{A}$.

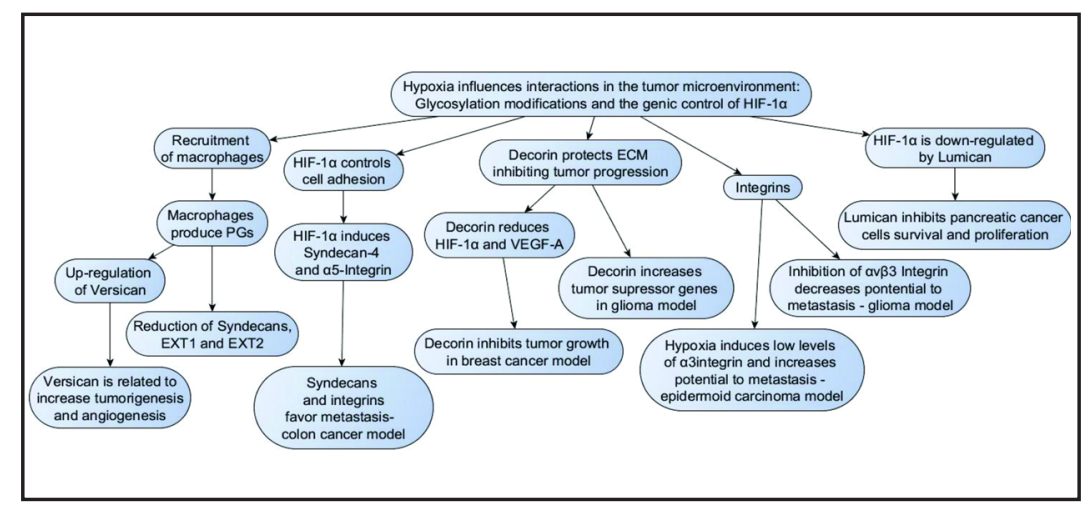

Hypoxia Alters Cell Location of Galectins And Interaction with their Ligands

Galectins are part of the vast family of lectins, with one conserved carbohydraterecognition domain (CRD) and an affinity for $\beta$-galactose-containing glycans [189]. Presently, 16 mammalian galectins have been identified, which can be divided into three groups: Prototype galectins (galectin-1, $-2,-5,-7,-10,-11,-13,-14,-15$, and -16), containing one CRD per subunit and that can bind non-covalently, forming homodimers; tandem-repeat galectins (galectin-4, -6, -8, -9, and -12), with two CRDs connected by a functional peptide; and one chimeric galectin- 3 , which contains a CRD and a proline-glycine-rich $\mathrm{N}$-terminal domain. Of all these, two are murine (galectin-5 and -6) and two presents in ruminants (galectin-11 and -12) [190, 191].

Since galectins can form dimers and oligomeric structures, their functions are based on complexes with carbohydrate formations, resulting in the accumulation of these multivalent glycoconjugates [192]. When present on the cell surface and the extracellular environment, these structures can activate signaling pathways by regulating membrane receptors, promoting cell-cell adhesion and cell-matrix processes [193]. The wide cellular distribution of galectins contributes to a functional variety of these proteins, which are essential in several physiological processes, such as homeostasis of T cells [194].

However, galectins have been associated with many disease processes, most notably in cancer, contributing to a variety of events, such as transformation of cancer cells via oncogenic Ras protein $[195,196]$. Moreover, as described, galectins promote cell adhesion, contributing to invasion and metastasis processes by tumor cells [191].

Angiogenesis is an important process for the progression of hypoxic tumors $[197,198]$. Gal-1, the first protein identified within the galectin family, shows involvement in tumor angiogenesis, and it was first suggested that both vascular smooth muscle and endothelial cells express the protein [199]. Gal-1 also modulates the expression of six other hypoxiarelated genes that are implicated in angiogenesis (i.e., CTGF, ATF3 (activating transcription factor 3), PPP1R15A (protein phosphate 1 regulatory subunity 15A), HSPA5 (heat shock protein family A member 5), TRA1 (transcription-associated protein 1) and CYR61 (cysteine rich angiogenic inducer 61) [200]. Clausse et al. have also previously shown that galectin-1 was upregulated in capillaries associated with carcinoma cells, and could mediate interactions between tumors and endothelial cells in vitro, suggesting a potential role for Gal-1 in modulating angiogenesis [201, 202].

Lectin interactions with end ogenous glycans control cell signaling and neovascularization $[96,203]$ and, therefore, can provide important information about hypoxic environments. When performing in vitro studies, Croci and Rabinovich (2014) observed that serum-free conditioned medium from an anti-VEGF refractory, but not anti-VEGF sensitive tumors, induced endothelial cell exposure of Gal-1-specific ligands. Large amounts of sialic acid $\alpha 2,6$ were found in tumor-associated vessels from mice inoculated with tumors that were sensitive to anti-VEGF (B16-F0 melanoma and CT26 colon carcinoma) in response to VEGF blockade, which prevented Gal-1 binding and angiogenesis [204]. In two studies, the author 
identified a compensatory mechanism in which the direct association of Gal-1 with complex $\mathrm{N}$-glycans on VEGFR2 domains may substitute for the absence of VEGF-A to promote EC signaling and preserve the angiogenic phenotype. A hypoxic microenvironment influences the glycan profile of HUVEC EC, increasing essential glycans for Gal-1 binding, including $\beta 1-6 G l c N A c-b r a n c h e d ~ N$-glycans and poly-LacNAc structures. Disruption of Gal1- $N$-glycan interactions promoted transient regularization of tumor-associated vasculature in vivo, and facilitated the influx of immune cells into the tumor microenvironment. This offers a novel alternative to evade resistance to VEGF-targeted therapies [85, 204].

Gal-1 can be found in the nucleus and the intracellular face of the cell membrane, but is mainly in cytoplasm, and is secreted by a non-canonical secretory pathway [205]. This protein has been known as a direct target of HIF-1 $\alpha$ [206].

Kaposi's sarcoma cells exhibit altered expression of Gal-1, which is directly induced by the presence of hypoxia and infection by human herpesvirus [204]. In head and neck carcinoma cell lines (FaDu), Gal-1 transcriptional levels were upregulated after $24 \mathrm{~h}$ of hypoxia treatment $\left(<0.01 \% \mathrm{O}_{2}\right)$ and Gal-1 post-translational and secreted levels were elevated in $12 \mathrm{~h}$, under both $2 \%$ and $0.2 \%$ hypoxia. The inversely proportional relationship between Gal-1 and T cell markers in vivo suggests that hypoxia-induced upregulation of galectin-1 is essential to the immune system escape process [205].

In a renal carcinoma cell line (CAK-1), Gal-1 expression increased proportionally with $\mathrm{CoCl} 2$ doses, which mimics a hypoxic environment by inhibiting the degradation of HIF$1 \alpha$. Increased Gal-1 levels favor cell migration and promote phosphorylation of Akt, mTOR (mechanistic target of rapamycin), and p70 kinase, which are involved in proliferation, cell growth, and survival processes [206].

There is an increasing number of studies that evaluate galectins- 1 and -3 expressions in tumors associated with the central nervous system, especially gliomas and glioblastomas, in addition to hypoxic tumors [207-210]. According to Le Mercier et al., Gal-1 expression is increased under hypoxic conditions. Partial blocking of Gal-1 expression by siRNA administration in Hs683 orthotopic xenografts in mouse brains reduced endoplasmic reticulum stress and enhanced the therapeutic benefits of temozolomide, a pro-autophagy drug [200].

In a xenotransplant model of glioblastoma multiform, the accumulation of cells that express high levels of Gal-3 in specific hypoxic areas called pseudopalisades, regions around the necrotic tissue was observed. Additionally, in hybrid human/murine glioblastoma cell line (NG97ht) there were positive changes in the expression of Gal-3, dependent on HIF$1 \alpha$ and NF-kB, under conditions that mimic a hypoxic microenvironment with nutrient deprivation. Association of these glycoprotein levels with cell survival, evidenced by Gal-3 silencing, increased the relative amount of death in the same cell line [211].

Gal-3 is the only galectin that belongs to the chimera subgroup. It is found in normal tissue and is highly expressed in many cancers [212]. Gal-3 is involved in cell growth, differentiation, adhesion, mRNA processing, and angiogenesis [213, 214].

Gal-3 is present in many compartments of cancer cells, including cytoplasm, acting in apoptosis inhibition [215]; in nucleus, regulating selective expression of some genes [216]; secreted, allowing for cell adhesion; and interacting with ECM [217]. In a microarray study, Olbryt et al. identified more than 430 hypoxia-responsive genes, including Gal-3 and its ligand fibronectin 1, in murine melanoma cell line (B16-F10) in vitro. They are associated with melanoma, but have not been reported to be regulated by hypoxia in human melanoma cells [218].

Gal-3 has been considered a tumor-associated antigen of malignancy level in breast cancer, and is implicated in aspects, such as angiogenesis [219], adhesion [220], invasion [221], apoptosis inhibition [222], migration [223], and therapeutic resistance [224]. Chen et al., through hydrazide-based chemistry method combined with liquid chromatography tandem-mass spectrometry (LC-MS/MS), identified 72 unique N-linked glycoproteins that were significantly regulated in triple negative breast cancers, among which is LGALS3BP. LGALS3BP is a highly-glycosylated galectin-3 binding protein whose bio-physiological 
Fig. 7. Expression and role of galectins- 1 and -3 in a hypoxic microenvironment. Galectins can play an important role in different phases of tumorigenic processes. Distant from blood vessel, cells can have an adaptive response caused by hypoxia, which include interactions between cell-cell and cell-extracellular matrix, leading to migration, invasion, and development through adhesion with endothelial cells. Moreover, high expression of galectins, mainly Gal-1, in this microenvironment might induce apoptosis of $\mathrm{T}$ cells, decreasing the immune response in tumors.

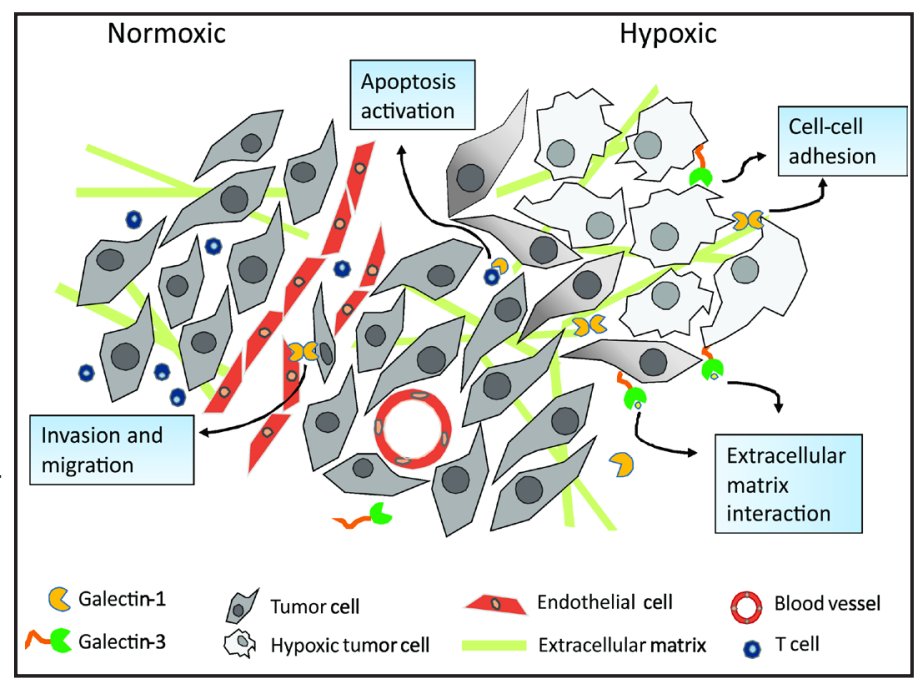

activity is not yet well defined, but recent findings point to a possible involvement with cancer growth and progression [225].

Immunohistochemical studies performed by our group showed that Gal-3 expression, in invasive and in situ ductal carcinoma of breast, was significantly higher among those with hypoxic regions. We also observed that Gal-1 expression was found mainly in the extracellular matrix and tumor-associated stromal cells, demonstrating their importance in the relationship between a tumor and its microenvironment [226, 227].

The amount of studies with galectins and hypoxic microenvironments in cancer demonstrates the key role of these glycan-binding proteins for tumor development and progression (Fig. 7). Galectins, mainly gal-1 and -3 , may be actively participating in the molecular machinery needed for cancer maintenance and are important targets for therapeutic research, as possible factors for cancer diagnoses, prognosis, and treatment.

\section{O-Glcnacylation Regulates Cell Survival Under Hypoxic Conditions}

O-GlcNAcylation is an important post-translational modification involved in regulating gene transcription, cellular signaling, and stress response under normal conditions. It occurs exclusively in the cytoplasm/nucleus, and is more similar to phosphorylation than to conventional glycosylation. Aberrant O-GlcNAcylation in cancer regulates glycolysis and reroutes metabolism pathways for cell survival and proliferation, and are involved invasion and metastasis processes $[228,229]$.

A study performed by Ferrer and collaborators showed that O-GlcNAcylation is increased in breast cancer cells MDA-MB-231 cultured under hypoxic conditions $\left(1 \% \mathrm{O}_{2}\right)$. This process is responsible for regulating survival stress signaling via regulation of HIF-1 $\alpha$ protein stability and degradation. Moreover, elevation of O-GlcNAcylation and O-GlcNAc transferase (the enzyme that catalyzes the transfer of the GlcNAc moiety to Ser/Thr residues) is associated with the expression of HIF-1 transcriptional targets that directly regulate glucose metabolism [230].

In PK4A mouse pancreatic cancer cells, it was observed that there was a $40 \%$ increase of O-GlcNAcylation protein levels in hypoxia when compared to normoxia. Cells cultured in glucose-free media, in addition to GlcNAc metabolite, increased the amount of O-GlcNAc protein from $86 \%$ (normoxia) to $150 \%$ (hypoxia). In PK4A cells, and in vivo mouse model, transcripts of enzymes involved in O-GlcNAcylation processes, such as O-GlcNAc transferase and O-GlcNAcase, are upregulated under hypoxic conditions. Taken together, these results indicate that 0-GlcNAcylation of proteins is dependent on glucose and glutamine availability, and is required for hypoxic pancreatic cancer survival [96]. 


\section{Cellular Physiology Cell Physiol Biochem 2017;41:1801-1829 \\ \begin{tabular}{ll|l} 
DOI: 10.1159/000471912 & O 2017 The Author(s). Published by S. Karger AG, Basel \\
wwww.karger.com/cpb
\end{tabular} \\ Silva-filho et al.: Glycobiology Alterations in Tumor Hypoxia}

O-GlcNAcylation also plays an important role in the metabolism regulation of lung cancer. In non-small cell lung carcinoma (H1299), hypoxia induces O-GlcNAcylation at serine 529 of PFK1 (6-Phosphoructokinase 1), an important enzyme of the glycolytic pathway, decreasing its activity. PFK1 O-GlcNAcylation redirects most of the glucose flux through the PPP and increases biosynthetic precursors, promoting cancer cell survival [231]. Rao et al. showed that O-GlcNAcylation of G6PD is upregulated in primary human lung cancer tissue samples, and in A549 lung cancer cells. Under hypoxic conditions $\left(1 \% \mathrm{O}_{2}\right), 0$-GlcNAcylation of G6PD in A549 cells induces upregulation in PPP flux, promoting the production of precursors involved in nucleotide biosynthesis and cell proliferation. Thus, modulation of PFK1 and G6PD glycosylation may provide new strategies for lung cancer therapy [41].

\section{Conclusion and Perspectives}

Several therapeutic strategies for cancer has been studied and developed by researchers from around the world. Among the main ones stands out the inhibition / silencing of galectins and other carbohydrate binding proteins, the use of combination therapy, the improvement of drug delivery by nanostructures, and the use of hypoxia-activated drugs.

Galectins are the most well studied tumor-associated carbohydrate binding proteins and so many techniques have been implemented to promote the blockage of galectin activity in cancer [232]. Inhibition of galectin expression, using siRNA or antisense sequences, showed significant results in colon [233], ovarian [234], esophageal [235], hepatocarcinoma [236], glioma [237], glioblastoma [238], and melanoma [239] cell lines. Anti-galectin mAbs and Gal-3 recombinant were also effective in vitro studies with diverse cell lines [240242]. Other galectin inhibition methods that showed some success including inhibition of biosynthesis of tumor-associated antigens [243], use of modified citrus pectin (MCP) [244], small carbohydrate-based inhibitors, such as ß-galactosides [245], and multivalent and allosteric inhibitors, among others [232].

Because its importance in maintaining tumor energy metabolism, glycolysis is also considered a field of therapeutic opportunities. Glucose analog 2-DG was used in patients for the first time in the 1950s and has been the most widely-investigated therapeutic agent in cancer glycolysis. However, since then, 2-DG has been ineffective in reducing tumor growth and another anti-glycolytic agent, such as Lonidamin, similarly failed to show efficacy in several cancers [246, 247].

More drugs and glycoproteins have emerged as possible alternative therapeutic targets for cancer. Tamoxifen, an endocrine therapy drug used to treat estrogen-receptor-positive breast cancer, is already used in the clinic and has been demonstrating that part of its activity may be linked to its "power" to modulate glycomolecules. This drug has a significant number of effects, including inhibition of sphingolipid metabolism through the impediment of ceramide glycosylation [248].

Other strategy is the combination of two or more therapeutic agents, Pusapati et al. found that simultaneous inhibition of glycolysis and mTORC1 signaling prevented in vitro and in vivo tumor cell growth. Once activated, mTORC1 directs the increase of glucose flux via the pentose phosphate pathway back into glycolysis, avoiding the glycolysis block and ensuring adequate ATP production. These findings reveal the important benefits of possible therapeutic improvement by targeting the Warburg effect [249].

Glycosylation of nanoparticles (NP) has also been utilized to target and deliver therapeutic drugs to malignant cells, and some TACA constitute potential targets for vaccine design. Still, one of the greatest obstacles in developing anticancer vaccines lies in choosing the right antigen, given inter and intratumor heterogeneity, and the fact that some carbohydrate antigens may also be present in normal tissues [250]. Recently, there has been a growing amount of research that looks for solutions to this problem, illustrating the possibility of targeting, silencing, and/or monitoring galectin or glycan expression using NP-based platforms [251-256]. 


\section{Cellular Physiology Cell Physiol Biochem 2017;41:1801-1829 \begin{tabular}{l|l} 
and Biochemistry Published on/Ine:April03, 2017 & $\begin{array}{l}\text { (c) 2017 The Author(s). Published by S. Karger AG, Basel } \\
\text { www.karger.com/cpb }\end{array}$ \\
\hline
\end{tabular} \\ Silva-filho et al.: Glycobiology Alterations in Tumor Hypoxia}

In addition to the "glyco" component, tumor microenvironment characteristics should be considered for the selection and development of new drugs and therapeutic approaches. Hypoxia-activated prodrugs, gene therapy, recombinant anaerobic bacteria, specific targeting of HIFs, or targeting pathways important in hypoxic cells, such as the mTOR and UPR (unfolded protein response) pathways, are current strategies proposed for targeting hypoxic tumor cells [22]. Among the hypoxia-activated prodrugs that have been developed are TH-302 (Evofosfamide) [257], E09 (Apaziquone) [258], and Tirapazamine (TPZ) [259]. However, there are no studies analyzing glycan processing inhibition and hypoxic sensitizers as a synergistic strategy to treat cancer cells. This therapeutic strategy seems to be promising and should be investigated by glycobiology and oncology researchers.

Aberrant glycosylation has presently emerged as a major hallmark of cancer. It has been elucidated that ligand-receptor interactions involving carbohydrates are modified by tumor microenvironment conditions, such as hypoxia. There is a need for more extensive characterization of glycosylation changes associated with carcinogenesis in order to identify novel biomarkers, mainly in the context of hypoxia. Furthermore, this needs to be accompanied by a better understanding of the basis of these changes and their relation to cancer phenotypes.

\section{Disclosure Statement}

The authors declare no conflicts of interest.

\section{References}

1 Tuccillo FM, De Laurentiis A, Palmieri C, Fiume G, Bonelli P, Borrelli A, Tassone P, Scala I, Buonaguro FM., Quinto I, Scala G: Aberrant glycosylation as biomarker for cancer: Focus on CD43. Biomed Res Int 2014;2014:742831.

-2 Monneau Y, Arenzana-seisdedos F, Lortat-jacob H: The sweet spot : how GAGs help chemokines guide migrating cells. J Leukoc Biol 2016;99:1-19.

-3 Drake RR: Chapter 1 - Glycosylation and Cancer: Moving Glycomics to the Forefront; in Research RRD and LEBBT-A in C (ed): Glycosylation and Cancer. Academic Press, 2015, pp 1-10.

-4 Christiansen MN, Chik J, Lee L, Anugraham M, Abrahams JL, Packer NH: Cell surface protein glycosylation in cancer. Proteomics 2014;14:525-546.

5 Pinho SS, Reis CA: Glycosylation in cancer: mechanisms and clinical implications. Nat Rev Cancer 2015;15:540-555.

Munkley J, Elliott DJ: Hallmarks of glycosylation in cancer. Oncotarget 2016;7:35478-35489. Sheta R, Woo CM, Roux-Dalvai F, Fournier F, Bourassa S, Droit A, Bertozzi CR, Bachvarov D: A metabolic labeling approach for glycoproteomic analysis reveals altered glycoprotein expression upon GALNT3 knockdown in ovarian cancer cells. J Proteomics 2016;145:91-102.

-8 Qiao Z, Dang C, Zhou B, Li S, Zhang W, Jiang J, Zhang J, Ma Y, Kong R, Ma Z: Downregulation of O-linked $\mathrm{N}$-acetylglucosamine transferase by RNA interference decreases MMP9 expression in human esophageal cancer cells. Oncol Lett 2016;11:3317-3323.

-9 Lucena MC, Carvalho-Cruz P, Donadio JL, Oliveira IA, de Queiroz RM, Marinho-Carvalho MM, de Paula IF, Gondim KC, McComb ME, Costello CE, Whelan AS, Todeschini AR, Dias WB: Epithelial Mesenchymal Transition Induces Aberrant Glycosylation through Hexosamine Biosynthetic Pathway Activation. J Biol Chem 2016;291:12917-12929.

10 Wu J, Qin H, Li T, Cheng K, Dong J, Tian M, Chai N, Guo H, Li J, You X, Dong M, Ye M, Nie Y, Zou H, Fan D: Characterization of site-specific glycosylation of secreted proteins associated with multi-drug resistance of gastric cancer. Oncotarget 2016;7:25315-25327.

- 11 Kannagi R, Sakuma K, Miyazaki K, Lim K-T, Yusa A, Yin J, Izawa M: Altered expression of glycan genes in cancers induced by epigenetic silencing and tumor hypoxia: clues in the ongoing search for new tumor markers. Cancer Sci 2010;101:586-593.

12 Lai M-C, Chang C-M, Sun HS: Hypoxia Induces Autophagy through Translational Up-Regulation of Lysosomal Proteins in Human Colon Cancer Cells. PLoS One 2016;11:e0153627. 


\section{Cellular Physiology Cell Physiol Biochem 2017;41:1801-1829

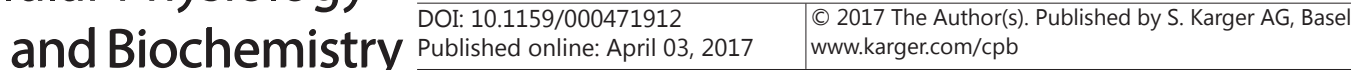

Silva-filho et al.: Glycobiology Alterations in Tumor Hypoxia

13 Ceyran AB, Şenol S, Güzelmeriç F, Tunçer E, Tongut A, Özbek B, Şavluk Ö, Aydın A, Ceyran H: Effects of hypoxia and its relationship with apoptosis, stem cells, and angiogenesis on the thymus of children with congenital heart defects: a morphological and immunohistochemical study. Int J Clin Exp Pathol 2015;8:8038-8047.

14 Huang S, Guo Y, Jacobi A, Li Z, Huang S, He J, Liu X, Tang Y: Aromatic Hydrocarbon Receptor Suppresses Prostate Cancer Bone Metastasis Cells-Induced Vasculogenesis of Endothelial Progenitor Cells under Hypoxia. Cell Physiol Biochem 2016;39:709-720.

-15 Sun W, Kosyna FK, Jelkmann W, Depping R: Prolyl-4-Hydroxylase 2 Potentially Contributes to Hepatocellular Carcinoma-Associated Erythrocytosis by Maintaining Hepatocyte Nuclear Factor-4alpha Expression. Cell Physiol Biochem 2015;37:2257-2264.

16 Hou S-Y, Li Y-P, Wang J-H, Yang S-L, Wang Y, Wang Y, Kuang Y: Aquaporin-3 Inhibition Reduces the Growth of NSCLC Cells Induced by Hypoxia. Cell Physiol Biochem 2016;38:129-140.

17 Guillaumond F, Iovanna JL, Vasseur S: Pancreatic tumor cell metabolism: focus on glycolysis and its connected metabolic pathways. Arch Biochem Biophys 2014;545:69-73.

18 Jin M-S, Lee H, Park IA, Chung YR, Im S-A, Lee K-H, Moon HG, Han W, Kim K, Kim TY, Noh DY, Ryu HS: Overexpression of HIF1alpha and CAXI predicts poor outcome in early-stage triple negative breast cancer. Virchows Arch 2016;469:183-190.

19 Abouhashem NS, Ibrahim DA, Mohamed AM: Prognostic implications of epithelial to mesenchymal transition related proteins (E-cadherin, Snail) and hypoxia inducible factor 1alpha in endometrioid endometrial carcinoma. Ann Diagn Pathol 2016;22:1-11.

20 Guo LY, Zhu P, Jin XP: Association between the expression of HIF-1alpha and VEGF and prognostic implications in primary liver cancer. Genet Mol Res DOI:10.4238/gmr.15028107

21 Rankin EB, Giaccia AJ: Hypoxic control of metastasis. Science 2016;352:175-180.

22 Wigerup C, Pahlman S, Bexell D: Therapeutic targeting of hypoxia and hypoxia-inducible factors in cancer. Pharmacol Ther 2016;164:152-169.

23 Lopez-Lazaro M: The warburg effect: why and how do cancer cells activate glycolysis in the presence of oxygen? Anticancer Agents Med Chem 2008;8:305-312.

24 Plecita-Hlavata L, Tauber J, Li M, Zhang H, Flockton AR, Pullamsetti SS, Chelladurai P, D'Alessandro A, El Kasmi KC, Ježek P, Stenmark KR: Constitutive Reprogramming of Fibroblast Mitochondrial Metabolism in Pulmonary Hypertension. Am J Respir Cell Mol Biol 2016;55:47-57.

25 Maher JC, Krishan A, Lampidis TJ: Greater cell cycle inhibition and cytotoxicity induced by 2-deoxyD-glucose in tumor cells treated under hypoxic vs aerobic conditions. Cancer Chemother Pharmacol 2004;53:116-122.

-26 Kurtoglu M, Gao N, Shang J, Maher JC, Lehrman MA, Wangpaichitr M, Savaraj N, Lane AN, Lampidis TJ: Under normoxia, 2-deoxy-D-glucose elicits cell death in select tumor types not by inhibition of glycolysis but by interfering with N-linked glycosylation. Mol Cancer Ther 2007;6:3049-3058.

27 Xi H, Kurtoglu M, Liu H, Wangpaichitr M, You M, Liu X, Savaraj N, Lampidis TJ: 2-Deoxy-D-glucose activates autophagy via endoplasmic reticulum stress rather than ATP depletion. Cancer Chemother Pharmacol 2011;67:899-910.

28 Deynoux M, Sunter N, Herault O, Mazurier F: Hypoxia and Hypoxia-Inducible Factors in Leukemias. Front Oncol 2016;6:41.

29 Yoshida GJ: Metabolic reprogramming: the emerging concept and associated therapeutic strategies. J Exp Clin Cancer Res 2015;34:111.

30 Devic S: Warburg Effect - a Consequence or the Cause of Carcinogenesis? J Cancer 2016;7:817-22.

-31 Zhao L, Mao Y, Zhao Y, Cao Y, Chen X: Role of multifaceted regulators in cancer glucose metabolism and their clinical significance. Oncotarget 2016;7:31572-31585.

-32 Yu L, Chen X, Wang L, Chen S: The sweet trap in tumors: aerobic glycolysis and potential targets for therapy. Oncotarget 2016;7:38908-38926.

-33 Lu H, Forbes RA, Verma A: Hypoxia-inducible factor 1 activation by aerobic glycolysis implicates the Warburg effect in carcinogenesis. J Biol Chem 2002;277:23111-23115.

-34 Marin-Hernandez A, Gallardo-Perez JC, Ralph SJ, Rodriguez-Enriquez S, Moreno-Sanchez R: HIF-1alpha modulates energy metabolism in cancer cells by inducing over-expression of specific glycolytic isoforms. Mini Rev Med Chem 2009;9:1084-1101.

- 35 Natsuizaka M, Ozasa M, Darmanin S, Miyamoto M, Kondo S, Kamada S, , Shindoh M, Higashino F, Suhara W, Koide H, Aita K, Nakagawa K, Kondo T, Asaka M, Okada F, Kobayashi M: Synergistic up-regulation of Hexokinase-2, glucose transporters and angiogenic factors in pancreatic cancer cells by glucose deprivation and hypoxia. Exp Cell Res 2007;313:3337-3348.

-36 Zhao F-Q Keating AF: Functional Properties and Genomics of Glucose Transporters. Curr Genomics 2007;8:113-128. 


\section{Cellular Physiology Cell Physiol Biochem 2017;41:1801-1829 \begin{tabular}{ll|l} 
and Biochemistry Published online: April03, 2017 & $\begin{array}{l}\text { (c) } 2017 \text { The Author(s). Published by S. Karger AG, Basel } \\
\text { www.karger.com/cpb }\end{array}$
\end{tabular}}

-37 Marin-Hernandez A, Rodriguez-Enriquez S, Vital-Gonzalez PA, Flores-Rodriguez FL, Macias-Silva M, Sosa-Garrocho M, Moreno-Sanchez R: Determining and understanding the control of glycolysis in fastgrowth tumor cells. Flux control by an over-expressed but strongly product-inhibited hexokinase. FEBS J 2006;273:1975-1988.

-38 Rankin EB, Giaccia AJ: The role of hypoxia-inducible factors in tumorigenesis. Cell Death Differ 2008;15:678-685.

-39 Prigione A, Rohwer N, Hoffmann S, Mlody B, Drews K, Bukowiecki R, Blumlein K, Wanker EE, Ralser M, Cramer T, Adjaye J: HIF1alpha modulates cell fate reprogramming through early glycolytic shift and upregulation of PDK1-3 and PKM2. Stem Cells 2014;32:364-376.

40 Bensaad K, Harris AL: Hypoxia and metabolism in cancer. Adv Exp Med Biol 2014;772:1-39.

41 Rao X, Duan X, Mao W, Li X, Li Z, Li Q Zheng Z, Xu H, Chen M, Wang PG, Wang Y, Shen B, Yi W: O-GlcNAcylation of G6PD promotes the pentose phosphate pathway and tumor growth. Nat Commun 2015;6:8468.

42 Kathagen-Buhmann A, Schulte A, Weller J, Holz M, Herold-Mende C, Glass R, Lamszus K: Glycolysis and the pentose phosphate pathway are differentially associated with the dichotomous regulation of glioblastoma cell migration versus proliferation. Neuro Oncol 2016;18:1219-1229.

-43 Kim J, Tchernyshyov I, Semenza GL, Dang C V: HIF-1-mediated expression of pyruvate dehydrogenase kinase: a metabolic switch required for cellular adaptation to hypoxia. Cell Metab 2006;3:177-185.

-44 Li X, Jiang Y, Meisenhelder J, Yang W, Hawke DH, Zheng Y, Xia Y, Aldape K, He J, Hunter T, Wang L, Lu Z: Mitochondria-Translocated PGK1 Functions as a Protein Kinase to Coordinate Glycolysis and the TCA Cycle in Tumorigenesis. Mol Cell 2016;61:705-719.

45 Huang D, Li C, Zhang H: Hypoxia and cancer cell metabolism. Acta Biochim Biophys Sin (Shanghai) 2014;46:214-219.

46 Harada H: Hypoxia-inducible factor 1-mediated characteristic features of cancer cells for tumor radioresistance. J Radiat Res 2016;57:i99-i105.

-47 Ekman M, Uvelius B, Albinsson S, Sward K: HIF-mediated metabolic switching in bladder outlet obstruction mitigates the relaxing effect of mitochondrial inhibition. Lab Invest 2014;94:557-568.

-48 Chen Z, Li Y, Zhang H, Huang P, Luthra R: Hypoxia-regulated microRNA-210 modulates mitochondrial function and decreases ISCU and COX10 expression. Oncogene 2010;29:4362-4368.

-49 Zois CE, Favaro E, Harris AL: Glycogen metabolism in cancer. Biochem Pharmacol 2014;92:3-11.

-50 Pescador N, Villar D, Cifuentes D, Garcia-Rocha M, Ortiz-Barahona A, Vazquez S, Ordonez A, Cuevas Y, Saez-Morales D, Garcia-Bermejo ML, Landazuri MO, Guinovart J, del Peso L: Hypoxia promotes glycogen accumulation through hypoxia inducible factor (HIF)-mediated induction of glycogen synthase 1. PLoS One 2010;5:e9644.

-51 Shen G-M, Zhang F-L, Liu X-L, Zhang J-W: Hypoxia-inducible factor 1-mediated regulation of PPP1R3C promotes glycogen accumulation in human MCF-7 cells under hypoxia. FEBS Lett 2010;584:4366-4372.

-52 Pelletier J, Bellot G, Gounon P, Lacas-Gervais S, Pouyssegur J, Mazure NM: Glycogen Synthesis is Induced in Hypoxia by the Hypoxia-Inducible Factor and Promotes Cancer Cell Survival. Front Oncol 2012;2:18.

-53 Liu Z, Jia X, Duan Y, Xiao H, Sundqvist K-G, Permert J, Wang F: Excess glucose induces hypoxia-inducible factor-1alpha in pancreatic cancer cells and stimulates glucose metabolism and cell migration. Cancer Biol Ther 2013;14:428-435.

-54 Kwon SJ, Lee YJ: Effect of low glutamine/glucose on hypoxia-induced elevation of hypoxia-inducible factor1alpha in human pancreatic cancer MiaPaCa-2 and human prostatic cancer DU-145 cells. Clin Cancer Res 2005;11:4694-4700.

55 Guppy M, Brunner S, Buchanan M: Metabolic depression: a response of cancer cells to hypoxia? Comp Biochem Physiol B Biochem Mol Biol 2005;140:233-239.

-56 Scott DA, Richardson AD, Filipp F V, Knutzen CA, Chiang GG, Ronai ZA, Osterman AL, Smith JW: Comparative metabolic flux profiling of melanoma cell lines: beyond the Warburg effect. J Biol Chem 2011;286:4262642634.

57 Payen VL, Brisson L, Dewhirst MW, Sonveaux P: Common responses of tumors and wounds to hypoxia. Cancer J 2015;21:75-87.

-58 Zhang G, Li J, Wang X, Ma Y, Yin X, Wang F, Zheng H, Duan X, Postel GC, Li X: The reverse Warburg effect and 18F-FDG uptake in non-small cell lung cancer A549 in mice: a pilot study. J Nucl Med 2015;56:607-612.

59 Liang D-M, Liu J-H, Wu H, Wang B-B, Zhu H-J, Qiao J-J: Glycosyltransferases: mechanisms and applications in natural product development. Chem Soc Rev 2015;44:8350-8374.

-60 Yamanami H, Shiozaki K, Wada T, Yamaguchi K, Uemura T, Kakugawa Y, Hujiya T, Miyagi T: Down-regulation of sialidase NEU4 may contribute to invasive properties of human colon cancers. Cancer Sci 2007;98:299307. 


\section{Cellular Physiology Cell Physiol Biochem 2017;41:1801-1829

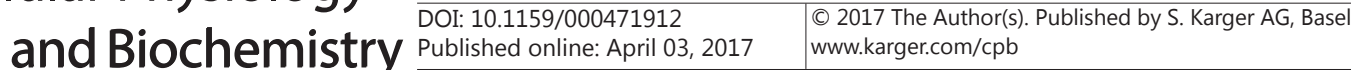

Silva-filho et al.: Glycobiology Alterations in Tumor Hypoxia

61 Wu W, Pan C, Meng K, Zhao L, Du L, Liu Q, Lin R: Hypoxia activates heparanase expression in an NF-kappaB dependent manner. Oncol Rep 2010;23:255-261.

62 Taniguchi N, Kizuka Y: Glycans and cancer: role of N-glycans in cancer biomarker, progression and metastasis, and therapeutics. Adv Cancer Res 2015;126:11-51.

63 Kalluri R, Weinberg RA: The basics of epithelial-mesenchymal transition. J Clin Invest 2009;119:14201428.

64 Xu Q, Akama R, Isaji T, Lu Y, Hashimoto H, Kariya Y, Fukuda T, Du Y, Gu J: Wnt/beta-catenin signaling downregulates $\mathrm{N}$-acetylglucosaminyltransferase III expression: the implications of two mutually exclusive pathways for regulation. J Biol Chem 2011;286:4310-4318.

65 Le Pendu J, Marionneau S, Cailleau-Thomas A, Rocher J, Le Moullac-Vaidye B, Clement M: ABH and Lewis histo-blood group antigens in cancer. APMIS 2001;109:9-31.

-66 Adamczyk B, Tharmalingam T, Rudd PM: Glycans as cancer biomarkers. Biochim Biophys Acta 2012;1820:1347-1353.

67 Bianco-Miotto T, Hussey DJ, Day TK, O’Keefe DS, Dobrovic A: DNA Methylation of the ABO Promoter Underlies Loss of ABO Allelic Expression in a Significant Proportion of Leukemic Patients. PLoS One 2009;4:e4788.

68 Koike T, Kimura N, Miyazaki K, Yabuta T, Kumamoto K, Takenoshita S, Chen J, Kobayashi M, Hosokawa M, Taniguchi A, Kojima T, Ishida N, Kawakita M, Yamamoto H, Takematsu H, Suzuki A, Kozutsumi Y, Kannagi R: Hypoxia induces adhesion molecules on cancer cells: A missing link between Warburg effect and induction of selectin-ligand carbohydrates. Proc Natl Acad Sci USA 2004;101:8132-8137.

69 Nonaka M, Fukuda MN, Gao C, Li Z, Zhang H, Greene MI, Peehl DM, Feizi T, Fukuda M: Determination of carbohydrate structure recognized by prostate-specific F77 monoclonal antibody through expression analysis of glycosyltransferase genes. J Biol Chem 2014;289:16478-16486.

-70 Croci DO, Cerliani JP, Dalotto-Moreno T, Mendez-Huergo SP, Mascanfroni ID, Dergan-Dylon S, Toscano MA, Caramelo JJ, García-Vallejo JJ, Ouyang J, Mesri EA, Junttila MR, Bais C, Shipp MA, Salatino M, Rabinovich GA: Glycosylation-dependent lectin-receptor interactions preserve angiogenesis in anti-VEGF refractory tumors. Cell 2014;156:744-758.

71 Kang R, Saito H, Ihara Y, Miyoshi E, Koyama N, Sheng Y, Taniguchi N: Transcriptional regulation of the $\mathrm{N}$-acetylglucosaminyltransferase $\mathrm{V}$ gene in human bile duct carcinoma cells (HuCC-T1) is mediated by Ets1. J Biol Chem 1996;271:26706-26712.

72 Ko JH, Miyoshi E, Noda K, Ekuni A, Kang R, Ikeda Y, Taniguchi N: Regulation of the GnT-V promoter by transcription factor Ets-1 in various cancer cell lines. J Biol Chem 1999;274:22941-22948.

73 Oikawa M, Abe M, Kurosawa H, Hida W, Shirato K, Sato Y: Hypoxia induces transcription factor ETS-1 via the activity of hypoxia-inducible factor-1. Biochem Biophys Res Commun 2001;289:39-43.

74 He X, Brenchley PEC, Jayson GC, Hampson L, Davies J, Hampson IN: Hypoxia increases heparanasedependent tumor cell invasion, which can be inhibited by antiheparanase antibodies. Cancer Res 2004;64:3928-3933.

75 Ma J, Lu X, Li X: [Effects of hypoxia on the expression of heparanase and invasiveness of Hep-2 laryngeal carcinoma cell]. Zhonghua Er Bi Yan Hou Tou Jing Wai Ke Za Zhi 2006;41:216-219.

76 Shiozaki K, Yamaguchi K, Takahashi K, Moriya S, Miyagi T: Regulation of sialyl Lewis antigen expression in colon cancer cells by sialidase NEU4. J Biol Chem 2011;286:21052-21061.

77 Gu J, Taniguchi N: Potential of N-glycan in cell adhesion and migration as either a positive or negative regulator. Cell Adh Migr 2008;2:243-245.

78 Taniguchi N: From the gamma-glutamyl cycle to the glycan cycle: a road with many turns and pleasant surprises. J Biol Chem 2009;284:34469-34478.

79 Partridge EA, Le Roy C, Di Guglielmo GM, Pawling J, Cheung P, Granovsky M, Pawling, J.; Cheung, P.; Granovsky, M.; Nabi, I.R.; Wrana, J.L.; Dennis, J.W: Regulation of cytokine receptors by Golgi N-glycan processing and endocytosis. Science 2004;306:120-124.

80 Rabinovich GA, Croci DO: Regulatory circuits mediated by lectin-glycan interactions in autoimmunity and cancer. Immunity 2012;36:322-335.

81 Rubinstein N, Alvarez M, Zwirner NW, Toscano MA, Ilarregui JM, Bravo A, Mordoh J, Fainboim L, Podhajcer OL, Rabinovich GA.: Targeted inhibition of galectin-1 gene expression in tumor cells results in heightened T cell-mediated rejection; A potential mechanism of tumor-immune privilege. Cancer Cell 2004;5:241-251.

82 Banh A, Zhang J, Cao H, Bouley DM, Kwok S, Kong C, Giaccia AJ, Koong AC, Le QT: Tumor galectin-1 mediates tumor growth and metastasis through regulation of T-cell apoptosis. Cancer Res 2011;71:4423-4431.

83 Dalotto-Moreno T, Croci DO, Cerliani JP, Martinez-Allo VC, Dergan-Dylon S, Mendez-Huergo SP, Stupirski JC, Mazal D, Osinaga E, Toscano MA, Sundblad V, Rabinovich GA, Salatino M: Targeting galectin-1 overcomes breast cancer-associated immunosuppression and prevents metastatic disease. Cancer Res 2013;73:11071117. 


\section{Cellular Physiology Cell Physiol Biochem 2017;41:1801-1829 \begin{tabular}{l|l} 
and Biochemistry Published on/Ine:April03, 2017 & $\begin{array}{l}\text { D } 2017 \text { The Author(s). Published by S. Karger AG, Basel } \\
\text { www.karger.com/cpb }\end{array}$ \\
\hline
\end{tabular}}

Silva-filho et al.: Glycobiology Alterations in Tumor Hypoxia

84 Belo AI, van Vliet SJ, Maus A, Laan LC, Nauta TD, Koolwijk P, Tefsen B, van Die I: Hypoxia inducible factor 1alpha down regulates cell surface expression of alpha1,2-fucosylated glycans in human pancreatic adenocarcinoma cells. FEBS Lett 2015;589:2359-2366.

-85 Zhang G, Zhang H, Wang Q Lal P, Carroll AM, de la Llera-Moya M, Xu X, Greene MI: Suppression of human prostate tumor growth by a unique prostate-specific monoclonal antibody F77 targeting a glycolipid marker. Proc Natl Acad Sci USA 2010;107:732-737.

86 Broquet P, George P, Geoffroy J, Reboul P, Louisot P: Study of O-glycan sialylation in C6 cultured glioma cells: evidence for post-translational regulation of a beta-galactoside alpha 2,3 sialyltransferase activity by N-glycosylation. Biochem Biophys Res Commun 1991;178:1437-1443.

87 Varki, Ajit; Cummings, Richard D; Esko, Jeffrey D; Freeze, Hudson H; Stanley, Pamela; Bertozzi, Carolyn R; Hart, Gerald W; Etzler ME: Essentials of Glycobiology. ed 2nd Cold Spring Harbor (NY), 2009.

-88 Natoni A, Macauley MS, O’Dwyer ME: Targeting Selectins and Their Ligands in Cancer. Front Oncol 2016;6:93.

89 Vlodavsky I, Friedmann Y, Elkin M, Aingorn H, Atzmon R, Ishai-Michaeli R, Bitan M, Pappo O, Peretz T, Michal I, Spector L, Pecker I: Mammalian heparanase: gene cloning, expression and function in tumor progression and metastasis. Nat Med 1999;5:793-802.

-90 Hulett MD, Freeman C, Hamdorf BJ, Baker RT, Harris MJ, Parish CR: Cloning of mammalian heparanase, an important enzyme in tumor invasion and metastasis. Nat Med 1999;5:803-809.

-91 Vlodavsky I, Elkin M, Pappo O, Aingorn H, Atzmon R, Ishai-Michaeli R, Aviv A, Pecker I, Friedmann Y: Mammalian heparanase as mediator of tumor metastasis and angiogenesis. Isr Med Assoc J 2000;2:37-45.

92 Olivares CN, Alaniz LD, Menger MD, Baranao RI, Laschke MW, Meresman GF: Inhibition of Hyaluronic Acid Synthesis Suppresses Angiogenesis in Developing Endometriotic Lesions. PLoS One 2016;11:e0152302.

-93 Kreil G: Hyaluronidases--a group of neglected enzymes. Protein Sci 1995;4:1666-1669.

$\$ 94$ Gao F, Okunieff P, Han Z, Ding I, Wang L, Liu W, Zhang J, Yang S, Chen J, Underhill CB, Kim S, Zhang L: Hypoxia-induced alterations in hyaluronan and hyaluronidase. Adv Exp Med Biol 2005;566:249-256.

\$5 Mikami Y, Hisatsune A, Tashiro T, Isohama Y, Katsuki H: Hypoxia enhances MUC1 expression in a lung adenocarcinoma cell line. Biochem Biophys Res Commun 2009;379:1060-1065.

-96 Guillaumond F, Leca J, Olivares O, Lavaut M-N, Vidal N, Berthezene P, Dusetti NJ, Loncle C, Calvo E, Turrini O, Iovanna JL, Tomasini R, Vasseur S: Strengthened glycolysis under hypoxia supports tumor symbiosis and hexosamine biosynthesis in pancreatic adenocarcinoma. Proc Natl Acad Sci USA 2013;110:3919-3924.

-97 Ren Y, Hao P, Law SKA, Sze SK: Hypoxia-induced changes to integrin alpha 3 glycosylation facilitate invasion in epidermoid carcinoma cell line A431. Mol Cell Proteomics 2014;13:3126-3137.

\$8 Hofmann BT, Schluter L, Lange P, Mercanoglu B, Ewald F, Fölster A, Picksak AS, Harder S, El Gammal AT, Grupp K, Güngör C, Drenckhan A, Schlüter H, Wagener C, Izbicki JR, Jücker M, Bockhorn M, Wolters-Eisfeld G.: COSMC knockdown mediated aberrant 0-glycosylation promotes oncogenic properties in pancreatic cancer. Mol Cancer 2015;14:109.

99 Chaika N V, Gebregiworgis T, Lewallen ME, Purohit V, Radhakrishnan P, Liu X, Zhang B, Mehla K, Brown RB, Caffrey T, Yu F, Johnson KR, Powers R, Hollingsworth MA, Singh PK: MUC1 mucin stabilizes and activates hypoxia-inducible factor 1 alpha to regulate metabolism in pancreatic cancer. Proc Natl Acad Sci USA 2012;109:13787-13792.

100 Potter CPS, Harris AL: Diagnostic, prognostic and therapeutic implications of carbonic anhydrases in cancer. Br J Cancer 2003;89:2-7.

101 Li Y, Wang H, Tu C, Shiverick KT, Silverman DN, Frost SC: Role of hypoxia and EGF on expression, activity, localization and phosphorylation of carbonic anhydrase IX in MDA-MB-231 breast cancer cells. Biochim Biophys Acta 2011;1813:159-167.

102 Ivanov S, Liao S-Y, Ivanova A, Danilkovitch-Miagkova A, Tarasova N, Weirich G, Merrill MJ, Proescholdt MA, Oldfield EH, Lee J, Zavada J, Waheed A, Sly W, Lerman MI, Stanbridge EJ: Expression of Hypoxia-Inducible Cell-Surface Transmembrane Carbonic Anhydrases in Human Cancer. Am J Pathol 2001;158:905-919.

103 Gomord V, Fitchette A-C, Menu-Bouaouiche L, Saint-Jore-Dupas C, Plasson C, Michaud D, Faye L: Plantspecific glycosylation patterns in the context of therapeutic protein production. Plant Biotechnol J 2010;8:564-587.

104 Schwarz F, Aebi M: Mechanisms and principles of N-linked protein glycosylation. Curr Opin Struct Biol 2011;21:576-582.

105 Chen C-Y, Jan Y-H, Juan Y-H, Yang C-J, Huang M-S, Yu C-J, Yang PC, Hsiao M, Hsu TL, Wong CH: Fucosyltransferase 8 as a functional regulator of nonsmall cell lung cancer. Proc Natl Acad Sci USA 2013;110:630-635. 


\section{Cellular Physiology Cell Physiol Biochem 2017;41:1801-1829 and Biochemistry Published onIIne: April03, $2017 \quad \begin{aligned} & \text { DOI: 10.1159/000471912 } 2017 \text { The Author(s). Published by S. Karger AG, Basel } \\ & \text { www.karger.com/cpb }\end{aligned}$}

Silva-filho et al.: Glycobiology Alterations in Tumor Hypoxia

106 Li N, Xu H, Fan K, Liu X, Qi J, Zhao C, Yin P, Wang L, Li Z, Zha X: Altered $\beta 1,6$-GlcNAc branched N-glycans impair TGF- $\beta$-mediated Epithelial-to-Mesenchymal Transition through Smad signalling pathway in human lung cancer. J Cell Mol Med 2014;18:1975-1991.

107 Brockhausen I, Yang J, Lehotay M, Ogata S, Itzkowitz S: Pathways of mucin O-glycosylation in normal and malignant rat colonic epithelial cells reveal a mechanism for cancer-associated Sialyl-Tn antigen expression. Biol Chem 2001;382:219-232.

108 Stowell SR, Ju T, Cummings RD: Protein glycosylation in cancer. Annu Rev Pathol 2015;10:473-510.

109 Lommel M, Strahl S: Protein 0-mannosylation: conserved from bacteria to humans. Glycobiology 2009;19:816-828.

110 Tailford LE, Crost EH, Kavanaugh D, Juge N: Mucin glycan foraging in the human gut microbiome. Front Genet 2015;6:81.

111 Spiro RG: Protein glycosylation: nature, distribution, enzymatic formation, and disease implications of glycopeptide bonds. Glycobiology 2002;12:43R-56R.

112 Brockhausen I: Pathways of O-glycan biosynthesis in cancer cells. Biochim Biophys Acta 1999;1473:67-95.

-113 Patil SA, Bshara W, Morrison C, Chandrasekaran E V, Matta KL, Neelamegham S: Overexpression of alpha2,3sialyl T-antigen in breast cancer determined by miniaturized glycosyltransferase assays and confirmed using tissue microarray immunohistochemical analysis. Glycoconj J 2014;31:509-521.

114 Munkley J: The Role of Sialyl-Tn in Cancer. Int J Mol Sci 2016;17:275.

115 Bapu D, Runions J, Kadhim M, Brooks SA: N-acetylgalactosamine glycans function in cancer cell adhesion to endothelial cells: A role for truncated O-glycans in metastatic mechanisms. Cancer Lett 2016;375:367-374.

116 Wang X, Yan F, Shi R, Huang X, Lu S, Xu L, Ren B: Hyper Expression of Mucin 5ac Indicates Poor Cancer Prognoses: A Meta-Analysis. Medicine (Baltimore) 2016;95:e2396.

-117 Hiraki M, Suzuki Y, Alam M, Hinohara K, Hasegawa M, Jin C, Kharbanda S, Kufe D: MUC1-C Stabilizes MCL1 in the Oxidative Stress Response of Triple-Negative Breast Cancer Cells to BCL-2 Inhibitors. Sci Rep 2016;6:26643.

118 Yin L, Kharbanda S, Kufe D: Mucin 1 oncoprotein blocks hypoxia-inducible factor 1alpha activation in a survival response to hypoxia. J Biol Chem 2007;282:257-266.

119 Aubert S, Fauquette V, Hemon B, Lepoivre R, Briez N, Bernard D, Van Seuningen I, Leroy X, Perrais M: MUC1, a new hypoxia inducible factor target gene, is an actor in clear renal cell carcinoma tumor progression. Cancer Res 2009;69:5707-5715.

120 Kitamoto S, Yokoyama S, Higashi M, Yamada N, Takao S, Yonezawa S: MUC1 enhances hypoxia-driven angiogenesis through the regulation of multiple proangiogenic factors. Oncogene 2013;32:4614-4621.

121 Hirono S, Yamaue H, Hoshikawa Y, Ina S, Tani M, Kawai M, Ushijima M, Matsuura M, Saiki Y, Saiura A, Yamamoto J, Miki Y, Noda T: Molecular markers associated with lymph node metastasis in pancreatic ductal adenocarcinoma by genome-wide expression profiling. Cancer Sci 2010;101:259-266.

122 Kitamoto S, Yokoyama S, Higashi M, Yamada N, Matsubara S, Takao S, Batra SK, Yonezawa S: Expression of MUC17 is regulated by HIF1alpha-mediated hypoxic responses and requires a methylation-free hypoxia responsible element in pancreatic cancer. PLoS One 2012;7:e44108.

123 Senapati S, Ho SB, Sharma P, Das S, Chakraborty S, Kaur S, Niehans G, Batra SK: Expression of intestinal MUC17 membrane-bound mucin in inflammatory and neoplastic diseases of the colon. J Clin Pathol 2010;63:702-707.

124 Huang A-F, Chen M-W, Huang S-M, Kao C-L, Lai H-C, Chan JY-H: CD164 regulates the tumorigenesis of ovarian surface epithelial cells through the SDF-1alpha/CXCR4 axis. Mol Cancer 2013;12:115.

125 Tang J, Luo Z, Zhou G, Song C, Yu F, Xiang J, Li G: Cis-regulatory functions of overlapping HIF-1alpha/E-box/ AP-1-like sequences of CD164. BMC Mol Biol 2011;12:44.

126 Furukawa J, Tsuda M, Okada K, Kimura T, Piao J, Tanaka S, Shinohara Y: Comprehensive Glycomics of a Multistep Human Brain Tumor Model Reveals Specific Glycosylation Patterns Related to Malignancy. PLoS One 2015;10:e0128300.

127 Vajaria BN, Patel KR, Begum R, Patel PS: Sialylation: an Avenue to Target Cancer Cells. Pathol Oncol Res 2016;22:443-447.

-128 Yin J, Miyazaki K, Shaner RL, Merrill AHJ, Kannagi R: Altered sphingolipid metabolism induced by tumor hypoxia - new vistas in glycolipid tumor markers. FEBS Lett 2010;584:1872-1878.

129 Tanaka K, Tamiya-Koizumi K, Yamada M, Murate T, Kannagi R, Kyogashima M: Individual profiles of free ceramide species and the constituent ceramide species of sphingomyelin and neutral glycosphingolipid and their alteration according to the sequential changes of environmental oxygen content in human colorectal cancer Caco-2 cel. Glycoconj J 2014;31:209-219.

130 Yeh S-C, Wang P-Y, Lou Y-W, Khoo K-H, Hsiao M, Hsu T-L, Wong C: Glycolipid GD3 and GD3 synthase are key drivers for glioblastoma stem cells and tumorigenicity. Proc Natl Acad Sci 2016;201604721. 


\section{Cellular Physiology Cell Physiol Biochem 2017;41:1801-1829

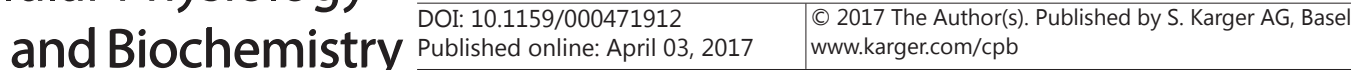

Silva-filho et al.: Glycobiology Alterations in Tumor Hypoxia

131 Yin J, Hashimoto A, Izawa M, Miyazaki K, Chen G-Y, Takematsu H, , Kozutsumi Y, Suzuki A, Furuhata K, Cheng F, Lin C, Sato C, Kitajima K, Kannagi R: Hypoxic culture induces expression of sialin, a sialic acid transporter, and cancer-associated gangliosides containing non-human sialic acid on human cancer cells. Cancer Res 2006;66:2937-2945.

132 Chou H-H, Hayakawa T, Diaz S, Krings M, Indriati E, Leakey M, Paabo S, Satta Y, Takahata N, Varki A: Inactivation of CMP-N-acetylneuraminic acid hydroxylase occurred prior to brain expansion during human evolution. Proc Natl Acad Sci USA 2002;99:11736-11741.

133 Guan F, Handa K, Hakomori S: Specific glycosphingolipids mediate epithelial-to-mesenchymal transition of human and mouse epithelial cell lines. Proc Natl Acad Sci USA 2009;106:7461-7466.

134 Guan F, Schaffer L, Handa K, Hakomori S-I: Functional role of gangliotetraosylceramide in epithelial-tomesenchymal transition process induced by hypoxia and by TGF-\{beta\}. FASEB J 2010;24:4889-4903.

135 Lluis JM, Buricchi F, Chiarugi P, Morales A, Fernandez-Checa JC: Dual role of mitochondrial reactive oxygen species in hypoxia signaling: activation of nuclear factor-\{kappa\}B via c-SRC and oxidant-dependent cell death. Cancer Res 2007;67:7368-7377.

136 De Maria R, Lenti L, Malisan F, d'Agostino F, Tomassini B, Zeuner A, Rippo M, Testi R: Requirement for GD3 ganglioside in CD95- and ceramide-induced apoptosis. Science 1997;277:1652-1655.

137 Colell A, Garcia-Ruiz C, Roman J, Ballesta A, Fernandez-Checa JC: Ganglioside GD3 enhances apoptosis by suppressing the nuclear factor-kappa B-dependent survival pathway. FASEB J Off Publ Fed Am Soc Exp Biol 2001;15:1068-1070.

138 Lluis JM, Llacuna L, von Montfort C, Barcena C, Enrich C, Morales A, Fernandez-Checa J: GD3 synthase overexpression sensitizes hepatocarcinoma cells to hypoxia and reduces tumor growth by suppressing the cSrc/NF-kappaB survival pathway. PLoS One 2009;4:e8059.

139 Alfonso S, Valdes-Zayas A, Santiesteban ER, Flores YI, Areces F, Hernandez M, Viada CE, Mendoza IC, Guerra PP, García E, Ortiz RA, de la Torre AV, Cepeda M, Pérez K, Chong E, Hernández AM, Toledo D, González Z, Mazorra Z, Crombet T, Pérez R, Vázquez AM, Macías AE: A randomized, multicenter, placebo-controlled clinical trial of racotumomab-alum vaccine as switch maintenance therapy in advanced non-small cell lung cancer patients. Clin Cancer Res 2014;20:3660-3671.

140 Horta ZP, Goldberg JL, Sondel PM: Anti-GD2 mAbs and next-generation mAb-based agents for cancer therapy. Immunotherapy 2016;8:1097-1117.

141 Tang H, Partyka K, Hsueh P, Sinha JY, Kletter D, Zeh H, Huang Y, Brand RE, Haab BB: Glycans related to the CA19-9 antigen are elevated in distinct subsets of pancreatic cancers and improve diagnostic accuracy over CA19-9. Cell Mol Gastroenterol Hepatol 2016;2:201-221.e15.

142 Taga M, Hoshino H, Low S, Imamura Y, Ito H, Yokoyama 0, Kobayashi M: A potential role for 6-sulfo sialyl Lewis X in metastasis of bladder urothelial carcinoma. Urol Oncol 2015;33:496.e1-9.

143 Ferreira JA, Magalhaes A, Gomes J, Peixoto A, Gaiteiro C, Fernandes E, Santos LL, Reis CA: Protein glycosylation in gastric and colorectal cancers: Toward cancer detection and targeted therapeutics. Cancer Lett 2017;387:32-45.

144 Desiderio V, Papagerakis P, Tirino V, Zheng L, Matossian M, Prince ME, Paino F, Mele L, Papaccio F, Montella R, Papaccio G, Papagerakis S: Increased fucosylation has a pivotal role in invasive and metastatic properties of head and neck cancer stem cells. Oncotarget 2015;6:71-84.

145 St Hill CA: Interactions between endothelial selectins and cancer cells regulate metastasis. Front Biosci (Landmark Ed) 2011;16:3233-3251.

146 Watanabe K, Oochiai T, Kikuchi S, Kumano T, Matsui T, Morimoto K, Yasukawa S, Nakamori S, Sasako M, Yanagisawa A, Otsuji E: Dermokine expression in intraductal papillary-mucinous neoplasm and invasive pancreatic carcinoma. Anticancer Res 2012;32:4405-4412.

147 Iozzo R V, Schaefer L: Proteoglycan form and function: A comprehensive nomenclature of proteoglycans. Matrix Biol 2015;42:11-55.

148 Couchman JR, Pataki CA: An introduction to proteoglycans and their localization. J Histochem Cytochem 2012;60:885-897.

149 Iozzo R V, Sanderson RD: Proteoglycans in cancer biology, tumour microenvironment and angiogenesis. J Cell Mol Med 2011;15:1013-1031.

150 Hultgardh-Nilsson A, Boren J, Chakravarti S: The small leucine-rich repeat proteoglycans in tissue repair and atherosclerosis. J Intern Med 2015;278:447-461.

151 Rauch U, Feng K, Zhou XH: Neurocan: a brain chondroitin sulfate proteoglycan. Cell Mol Life Sci 2001;58:1842-1856.

152 Miner JH: NIH Public Access 2013;318:973-978.

153 Yurchenco PD, Amenta PS, Patton BL: Basement membrane assembly, stability and activities observed through a developmental lens. Matrix Biol 2004;22:521-538. 


\section{Cellular Physiology Cell Physiol Biochem 2017;41:1801-1829

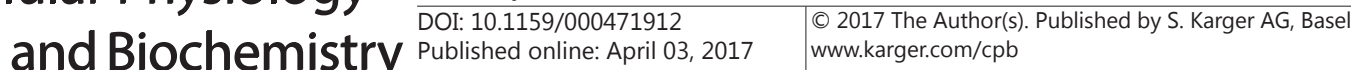

Silva-filho et al.: Glycobiology Alterations in Tumor Hypoxia

154 Glentis A, Gurchenkov V, Matic Vignjevic D: Assembly, heterogeneity, and breaching of the basement membranes. Cell Adh Migr 2014;8:236-245.

155 Cheng B, Montmasson M, Terradot L, Rousselle P: Syndecans as Cell Surface Receptors in Cancer Biology. A Focus on their Interaction with PDZ Domain Proteins. Front Pharmacol 2016;7:10.

156 Tarbell JM, Cancel LM: The glycocalyx and its significance in human medicine. J Intern Med 2016;280:97113.

157 Tamm C, Kjellén L, Li J-P: Heparan Sulfate Biosynthesis Enzymes in Embryonic Stem Cell Biology. J Histochem Cytochem 2012;60:943-949.

158 Sleeman JP: The metastatic niche and stromal progression. Cancer Metastasis Rev 2012;31:429-440.

159 Sceneay J, Smyth MJ, Moller A: The pre-metastatic niche: finding common ground. Cancer Metastasis Rev 2013;32:449-464.

160 Conejo JR, Kleeff J, Koliopanos A, Matsuda K, Zhu ZW, Goecke H, Bicheng N, Zimmermann A, Korc M, Friess $\mathrm{H}$, Büchler MW: Syndecan-1 expression is up-regulated in pancreatic but not in other gastrointestinal cancers. Int J cancer 2000;88:12-20.

-161 Aragao AZB, Belloni M, Simabuco FM, Zanetti MR, Yokoo S, Domingues RR, Kawahara R, Pauletti BA, Gonçalves A, Agostini M, Graner E, Coletta RD, Fox JW, Paes Leme AF: Novel processed form of syndecan-1 shed from SCC-9 cells plays a role in cell migration. PLoS One 2012; 7:e43521.

162 Couldrey C, E Green J: Metastases: the glycan connection. Breast Cancer Res 2000;2:321-323.

163 Sceneay J, Parker BS, Smyth MJ, Moller A: Hypoxia-driven immunosuppression contributes to the premetastatic niche. Oncoimmunology 2013;2:e22355.

164 Span PN, Bussink J: Biology of hypoxia. Semin Nucl Med 2015;45:101-109.

165 Wong CC-L, Zhang H, Gilkes DM, Chen J, Wei H, Chaturvedi P, Hubbi ME, Semenza GL: Inhibitors of hypoxiainducible factor 1 block breast cancer metastatic niche formation and lung metastasis. J Mol Med (Berl) 2012;90:803-815.

166 Lewis C, Murdoch C: Macrophage responses to hypoxia: implications for tumor progression and anticancer therapies. Am J Pathol 2005;167:627-635.

167 Jenster G: The role of the androgen receptor in the development and progression of prostate cancer. Semin Oncol 1999;26:407-421.

168 Whitelock JM, Iozzo R V: Heparan sulfate: a complex polymer charged with biological activity. Chem Rev 2005;105:2745-2764.

169 Asplund A, Ostergren-Lunden G, Camejo G, Stillemark-Billton P, Bondjers G: Hypoxia increases macrophage motility, possibly by decreasing the heparan sulfate proteoglycan biosynthesis. J Leukoc Biol 2009;86:381388.

170 Kawashima H, Atarashi K, Hirose M, Hirose J, Yamada S, Sugahara K, Miyasaka M: Oversulfated chondroitin/dermatan sulfates containing GlcAbeta1/IdoAalpha1-3GalNAc(4,6-0-disulfate) interact with L- and P-selectin and chemokines. J Biol Chem 2002;277:12921-12930.

-171 Zheng P-S, Reis M, Sparling C, Lee DY, La Pierre DP, Wong C-KA, Deng Z, Kahai S, Wen J, Yang BB: Versican G3 domain promotes blood coagulation through suppressing the activity of tissue factor pathway inhibitor-1. J Biol Chem 2006;281:8175-8182.

172 Bode-Lesniewska B, Dours-Zimmermann MT, Odermatt BF, Briner J, Heitz PU, Zimmermann DR: Distribution of the large aggregating proteoglycan versican in adult human tissues. J Histochem Cytochem 1996;44:303-312.

173 Sotoodehnejadnematalahi F, Burke B: Structure, function and regulation of versican: the most abundant type of proteoglycan in the extracellular matrix. Acta Med Iran 2013;51:740-750.

174 Sotoodehnejadnematalahi F, Staples KJ, Chrysanthou E, Pearson H, Ziegler-Heitbrock L, Burke B: Mechanisms of Hypoxic Up-Regulation of Versican Gene Expression in Macrophages. PLoS One 2015;10:e0125799.

175 Brezillon S, Pietraszek K, Maquart F-X, Wegrowski Y: Lumican effects in the control of tumour progression and their links with metalloproteinases and integrins. FEBS J 2013;280:2369-2381.

176 Nikitovic D, Katonis P, Tsatsakis A, Karamanos NK, Tzanakakis GN: Lumican, a small leucine-rich proteoglycan. IUBMB Life 2008;60:818-823.

$\rightarrow 177$ Vuillermoz B, Khoruzhenko A, D’Onofrio M-F, Ramont L, Venteo L, Perreau C, Antonicelli F, Maquart FX, Wegrowski Y: The small leucine-rich proteoglycan lumican inhibits melanoma progression. Exp Cell Res 2004;296:294-306.

178 Brezillon S, Zeltz C, Schneider L, Terryn C, Vuillermoz B, Ramont L, Perrau C, Pluot M, Diebold MD, Radwanska A, Malicka-Blaszkiewicz M, Maquart FX, Wegrowski Y: Lumican inhibits B16F1 melanoma cell lung metastasis. J Physiol Pharmacol 2009;60:15-22. 


\section{Cellular Physiology Cell Physiol Biochem 2017;41:1801-1829 \begin{tabular}{l|l} 
and Biochemistry & $\begin{array}{l}\text { DOI: 10.1159/000471912 } \\
\text { Published } 2017 \text { The Author(s). Published by S. Karger AG, Basel }\end{array}$ \\
\hline www.karger.com/cpb
\end{tabular}

179 Matsuda Y, Yamamoto T, Kudo M, Kawahara K, Kawamoto M, Nakajima Y, Koizumi K, Nakazawa N, Ishiwata T, Naito Z: Expression and roles of lumican in lung adenocarcinoma and squamous cell carcinoma. Int J Oncol 2008;33:1177-1185.

180 Li X, Truty MA, Kang Y, Chopin-Laly X, Zhang R, Roife D, Chatterjee D, Lin E, Thomas RM, Wang H: Extracellular lumican inhibits pancreatic cancer cell growth and is associated with prolonged survival after surgery. Clin Cancer Res 2014;20:6529-6540.

181 Neill T, Schaefer L, Iozzo R V: Decorin: a guardian from the matrix. Am J Pathol 2012;181:380-387.

182 Grant DS, Yenisey C, Rose RW, Tootell M, Santra M, Iozzo R V: Decorin suppresses tumor cell-mediated angiogenesis. Oncogene 2002;21:4765-4777.

183 Neill T, Painter H, Buraschi S, Owens RT, Lisanti MP, Schaefer L, Iozzo RV: Decorin antagonizes the angiogenic network: concurrent inhibition of Met, hypoxia inducible factor $1 \mathrm{alpha}$, vascular endothelial growth factor A, and induction of thrombospondin-1 and TIMP3. J Biol Chem 2012;287:5492-5506.

184 Santra M, Katakowski M, Zhang RL, Zhang ZG, Meng H, Jiang F, Chopp M: Protection of adult mouse progenitor cells and human glioma cells by de novo decorin expression in an oxygen- and glucose-deprived cell culture model system. J Cereb Blood Flow Metab 2006;26:1311-1322.

185 Pacold ME, Suire S, Perisic O, Lara-Gonzalez S, Davis CT, Walker EH, Hawkins PT, Stephens L, Eccleston JF, Williams RL: Crystal structure and functional analysis of Ras binding to its effector phosphoinositide 3-kinase gamma. Cell 2000;103:931-943.

186 Xu CS, Wang ZF, Huang XD, Dai LM, Cao CJ, Li ZQ: Involvement of ROS-alpha v beta 3 integrin-FAK/Pyk2 in the inhibitory effect of melatonin on U251 glioma cell migration and invasion under hypoxia. J Transl Med 2015;13:95.

187 Xiao L, Yue X, Ming X, Xu L, Ding M, Xu J, Liu Q: The integrin-linked kinase gene up-regulated by hypoxia plays its pro-survival role in colorectal cancer cells. J Recept Signal Transduct Res 2014;34:64-72.

188 You WK, Yotsumoto F, Sakimura K, Adams RH, Stallcup WB: NG2 proteoglycan promotes tumor vascularization via integrin-dependent effects on pericyte function. Angiogenesis 2014;17:61-76.

189 van der Hoeven NW, Hollander MR, Yildirim C, Jansen MF, Teunissen PF, Horrevoets AJ, Kraan T, Royen N: The emerging role of galectins in cardiovascular disease. Vascul Pharmacol 2016;81:31-41.

190 Saussez S, Kiss R: Galectin-7. Cell Mol Life Sci 2006;63:686-697.

191 Wang L, Guo X-L: Molecular regulation of galectin-3 expression and therapeutic implication in cancer progression. Biomed Pharmacother 2016;78:165-171.

192 Bojarova P, Kren V: Sugared biomaterial binding lectins: achievements and perspectives. Biomater Sci 2016;4:1142-1160.

193 Heusschen R, Griffioen AW, Thijssen VL: Galectin-9 in tumor biology: a jack of multiple trades. Biochim Biophys Acta 2013;1836:177-185.

194 Rabinovich GA, Toscano MA: Turning "sweet" on immunity: galectin-glycan interactions in immune tolerance and inflammation. Nat Rev Immunol 2009;9:338-352.

195 Elad-Sfadia G, Haklai R, Balan E, Kloog Y: Galectin-3 augments K-Ras activation and triggers a Ras signal that attenuates ERK but not phosphoinositide 3-kinase activity. J Biol Chem 2004;279:34922-34930.

196 Paz A, Haklai R, Elad-Sfadia G, Ballan E, Kloog Y: Galectin-1 binds oncogenic H-Ras to mediate Ras membrane anchorage and cell transformation. Oncogene 2001;20:7486-7493.

197 Meng F, Chen X, Song H, Lou G: LAPTM4B down regulation inhibits the proliferation, invasion and angiogenesis of HeLa cells in vitro. Cell Physiol Biochem 2015;37:890-900.

198 Iacobazzi D, Garaeva I, Albertario A, Cherif M, Angelini GD, Caputo M, Ghorbel MT: Protein Phosphatase 1 Beta is Modulated by Chronic Hypoxia and Involved in the Angiogenic Endothelial Cell Migration. Cell Physiol Biochem 2015;36:384-394.

199 Griffin RJ, Koonce NA, Dings RPM, Siegel E, Moros EG, Brauer-Krisch E, Corry PM: Microbeam radiation therapy alters vascular architecture and tumor oxygenation and is enhanced by a galectin- 1 targeted antiangiogenic peptide. Radiat Res 2012;177:804-812.

200 Le Mercier M, Mathieu V, Haibe-Kains B, Bontempi G, Mijatovic T, Kiss R, Lefranc F: Knocking down galectin 1 in human hs683 glioblastoma cells impairs both angiogenesis and endoplasmic reticulum stress responses. J Neuropathol Exp Neurol 2008;67:456-469.

-201 Clausse N, van den Brule F, Waltregny D, Garnier F, Castronovo V: Galectin-1 expression in prostate tumorassociated capillary endothelial cells is increased by prostate carcinoma cells and modulates heterotypic cell-cell adhesion. Angiogenesis 1999;3:317-325.

202 Le Mercier M, Fortin S, Mathieu V, Kiss R, Lefranc F: Galectins and gliomas. Brain Pathol 2010;20:17-27.

203 Bacigalupo ML, Manzi M, Rabinovich GA, Troncoso MF: Hierarchical and selective roles of galectins in hepatocarcinogenesis, liver fibrosis and inflammation of hepatocellular carcinoma. World J Gastroenterol 2013;19:8831-8849. 


\section{Cellular Physiology Cell Physiol Biochem 2017;41:1801-1829 and Biochemistry Published onlıne: Apri|03, $2017 \quad$\begin{tabular}{l|l} 
DOI: 10.1159/000471912 2017 The Author(s). Published by S. Karger AG, Basel \\
www.karger.com/cpb
\end{tabular}}

Silva-filho et al.: Glycobiology Alterations in Tumor Hypoxia

204 Croci DO, Salatino M, Rubinstein N, Cerliani JP, Cavallin LE, Leung HJ, Ouyang J, Ilarregui JM, Toscano MA, Domaica CI Croci MC, Shipp MA, Mesri EA, Albini A, Rabinovich GA: Disrupting galectin-1 interactions with $\mathrm{N}$-glycans suppresses hypoxia-driven angiogenesis and tumorigenesis in Kaposi's sarcoma. J Exp Med 2012;209:1985-2000.

205 Le Q-T, Shi G, Cao H, Nelson DW, Wang Y, Chen EY, Zhao S, Kong C, Richardson D, O’Byrne KJ, Giaccia AJ, Koong AC: Galectin-1: a link between tumor hypoxia and tumor immune privilege. J Clin Oncol 2005;23:8932-8941.

206 White NMA, Masui O, Newsted D, Scorilas A, Romaschin AD, Bjarnason GA, Siu KW, Yousef GM: Galectin-1 has potential prognostic significance and is implicated in clear cell renal cell carcinoma progression through the HIF/mTOR signaling axis. Br J Cancer 2014;110:1250-1259.

207 D’Haene N, Maris C, Rorive S, Decaestecker C, Le Mercier M, Salmon I: Galectins and neovascularization in central nervous system tumors. Glycobiology 2014;24:892-898.

208 Van Woensel M, Wauthoz N, Rosiere R, Mathieu V, Kiss R, Lefranc F, Steelant B, Dilissen E, Van Gool SW, Mathivet T, Gerhardt H, Amighi K, De Vleeschouwer S: Development of siRNA-loaded chitosan nanoparticles targeting Galectin-1 for the treatment of glioblastoma multiforme via intranasal administration. J Control Release 2016;227:71-81.

209 Verschuere T, Van Woensel M, Fieuws S, Lefranc F, Mathieu V, Kiss R, Van Gool SW, De Vleeschouwer S: Altered galectin-1 serum levels in patients diagnosed with high-grade glioma. J Neurooncol 2013;115:917.

210 Deininger MH, Trautmann K, Meyermann R, Schluesener HJ: Galectin-3 labeling correlates positively in tumor cells and negatively in endothelial cells with malignancy and poor prognosis in oligodendroglioma patients. Anticancer Res 2002;22:1585-1592.

211 Ikemori RY, Machado CML, Furuzawa KM, Nonogaki S, Osinaga E, Umezawa K, DE Carvalho MA, Verinaud L, Chammas R:: Galectin-3 Up-Regulation in Hypoxic and Nutrient Deprived Microenvironments Promotes Cell Survival. PLoS One 2014;9:e111592.

212 Song S, Ji B, Ramachandran V, Wang H, Hafley M, Logsdon C, Bresalier RS: Overexpressed galectin-3 in pancreatic cancer induces cell proliferation and invasion by binding Ras and activating Ras signaling. PLoS One 2012;7:e42699.

213 Yang R-Y, Rabinovich GA, Liu F-T: Galectins: structure, function and therapeutic potential. Expert Rev Mol Med 2008;10:e17.

214 Nangia-Makker P, Honjo Y, Sarvis R, Akahani S, Hogan V, Pienta KJ, Raz A: Galectin-3 Induces Endothelial Cell Morphogenesis and Angiogenesis. Am J Pathol 2000;156:899-909.

215 Califice S, Castronovo V, Bracke M, van den Brule F: Dual activities of galectin-3 in human prostate cancer: tumor suppression of nuclear galectin-3 vs tumor promotion of cytoplasmic galectin-3. Oncogene 2004;23:7527-7536.

216 Paron I, Scaloni A, Pines A, Bachi A, Liu F-T, Puppin C, Pandolfi M, Ledda L, Di Loreto C, Damante G, Tell G.: Nuclear localization of Galectin-3 in transformed thyroid cells: a role in transcriptional regulation. Biochem Biophys Res Commun 2003;302:545-553.

217 Camby I, Belot N, Rorive S, Lefranc F, Maurage CA, Lahm H, Kaltner H, Hadari Y, Ruchoux MM, Brotchi J, Zick Y, Salmon I, Gabius HJ, Kiss R: Galectins are differentially expressed in supratentorial pilocytic astrocytomas, astrocytomas, anaplastic astrocytomas and glioblastomas, and significantly modulate tumor astrocyte migration. Brain Pathol 2001;11:12-26.

218 Olbryt M, Habryka A, Tyszkiewicz T, Rusin A, Cichon T, Jarzab M, Krawczyk Z: Melanoma-associated genes, MXI1, FN1, and NME1, are hypoxia responsive in murine and human melanoma cells. Melanoma Res 2011;21:417-425.

219 Nangia-Makker P, Wang Y, Raz T, Tait L, Balan V, Hogan V, Raz A: Cleavage of galectin-3 by matrix metalloproteases induces angiogenesis in breast cancer. Int J cancer 2010;127:2530-2541.

220 Noma N, Simizu S, Kambayashi Y, Kabe Y, Suematsu M, Umezawa K: Involvement of NF-kappaB-mediated expression of galectin-3-binding protein in TNF-alpha-induced breast cancer cell adhesion. Oncol Rep 2012;27:2080-2084.

221 White MJ V, Roife D, Gomer RH: Galectin-3 Binding Protein Secreted by Breast Cancer Cells Inhibits Monocyte-Derived Fibrocyte Differentiation. J Immunol 2015;195:1858-1867.

222 Guha P, Bandyopadhyaya G, Polumuri SK, Chumsri S, Gade P, Kalvakolanu D V, Ahmed H: Nicotine promotes apoptosis resistance of breast cancer cells and enrichment of side population cells with cancer stem celllike properties via a signaling cascade involving galectin-3, alpha9 nicotinic acetylcholine receptor and STAT3. Breast Cancer Res Treat 2014;145:5-22.

223 Boscher C, Zheng YZ, Lakshminarayan R, Johannes L, Dennis JW, Foster LJ, Nabi IR: Galectin-3 protein regulates mobility of $\mathrm{N}$-cadherin and GM1 ganglioside at cell-cell junctions of mammary carcinoma cells. J Biol Chem 2012;287:32940-32952. 


\section{Cellular Physiology Cell Physiol Biochem 2017;41:1801-1829

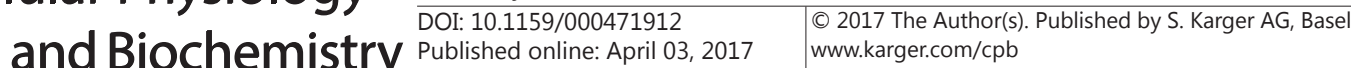 \\ Published online: Aprios,}

224 Amm HM, Buchsbaum DJ: Relationship between galectin-3 expression and TRAIL sensitivity in breast cancer. Expert Rev Anticancer Ther 2011;11:1193-1196.

225 Chen X, Wu J, Huang H, Ding Q, Liu X, Chen L, Zha X, Liang M, He J, Zhu Q Wang S, Xia T.: Comparative Profiling of Triple-Negative Breast Carcinomas Tissue Glycoproteome by Sequential Purification of Glycoproteins and Stable Isotope Labeling. Cell Physiol Biochem 2016;38:110-121.

226 Rego MJB de M, da Silva Filho AF, Cordeiro MF, Santos PB, Beltrao EIC: The glycomic profile of invasive ductal carcinoma of the breast is altered in patients with hypoxic regions: implications for tumor behavior. Folia Histochem Cytobiol 2014;52:96-103.

227 Rego MJB de M, Vieira de Mello GS, da Silva Santos CA, Chammas R, Beltrao EIC: Implications on glycobiological aspects of tumor hypoxia in breast ductal carcinoma in situ. Med Mol Morphol 2013;46:9296.

-228 Slawson C, Hart GW: O-GlcNAc signalling: implications for cancer cell biology. Nat Rev Cancer 2011;11:678-684.

229 Gu Y, Mi W, Ge Y, Liu H, Fan Q, Han C, Yang J, Han F, Lu X, Yu W: GlcNAcylation plays an essential role in breast cancer metastasis. Cancer Res 2010;70:6344-6351.

230 Ferrer CM, Lynch TP, Sodi VL, Falcone JN, Schwab LP, Peacock DL, Vocadlo DJ, Seagroves TN, Reginato MJ: O-GlcNAcylation regulates cancer metabolism and survival stress signaling via regulation of the HIF-1 pathway. Mol Cell 2014;54:820-831.

231 Yi W, Clark PM, Mason DE, Keenan MC, Hill C, Goddard WA 3rd, Peters EC., Driggers EM: Phosphofructokinase 1 glycosylation regulates cell growth and metabolism. Science 2012;337:975-980.

232 Rachel H, Chang-Chun L: Recent advances toward the development of inhibitors to attenuate tumor metastasis via the interruption of lectin-ligand interactions. Adv Carbohydr Chem Biochem 2013;69:125207.

233 Lu H, Liu Y, Wang D, Wang L, Zhou H, Xu G, Xie L, Wu M, Lin Z, Yu Y, Li G: Galectin-3 regulates metastatic capabilities and chemotherapy sensitivity in epithelial ovarian carcinoma via NF-kappaB pathway. Tumour Biol 2016;37:11469-11477.

234 Song S, Byrd JC, Mazurek N, Liu K, Koo JS, Bresalier RS: Galectin-3 modulates MUC2 mucin expression in human colon cancer cells at the level of transcription via AP-1 activation. Gastroenterology 2005;129:1581-1591.

235 Qiao L, Liang N, Xie J, Luo H, Zhang J, Deng G, , Li Y, Zhang J: Gene silencing of galectin-3 changes the biological behavior of Eca109 human esophageal cancer cells. Mol Med Rep 2016;13:160-166.

236 Li J, Sun R, Yu Z, Liang H, Shen S, Kan Q: Galectin-1 Modulates the Survival and Tumor Necrosis FactorRelated Apoptosis-Inducing Ligand (TRAIL) Sensitivity in Human Hepatocellular Carcinoma Cells. Cancer Biother Radiopharm 2015;30:336-341.

237 Strik HM, Schmidt K, Lingor P, Tonges L, Kugler W, Nitsche M, Rabinovich GA, Bahr M: Galectin-1 expression in human glioma cells: modulation by ionizing radiation and effects on tumor cell proliferation and migration. Oncol Rep 2007;18:483-488.

-238 Fortin S, Le Mercier M, Camby I, Spiegl-Kreinecker S, Berger W, Lefranc F, Kiss R: Galectin-1 is implicated in the protein kinase $\mathrm{C}$ epsilon/vimentin-controlled trafficking of integrin-beta1 in glioblastoma cells. Brain Pathol 2010;20:39-49.

239 Braeuer RR, Zigler M, Kamiya T, Dobroff AS, Huang L, Choi W, McConkey DJ, Shoshan E, Mobley AK, Song R, Raz A, Bar-Eli M: Galectin-3 contributes to melanoma growth and metastasis via regulation of NFAT1 and autotaxin. Cancer Res 2012;72:5757-5766.

240 van Beijnum JR, Thijssen VL, Lappchen T, Wong TJ, Verel I, Engbersen M, Schulkens IA, Rossin R Grull H, Griffioen AW, Nowak-Sliwinska PA: A key role for galectin-1 in sprouting angiogenesis revealed by novel rationally designed antibodies. Int J cancer 2016;139:824-835.

241 Meng F, Joshi B, Nabi IR: Galectin-3 Overrides PTRF/Cavin-1 Reduction of PC3 Prostate Cancer Cell Migration. PLoS One 2015;10:e0126056.

242 Fujihara S, Mori H, Kobara H, Rafiq K, Niki T, Hirashima M, Masaki T: Galectin-9 in cancer therapy. Recent Pat Endocr Metab Immune Drug Discov 2013;7:130-137.

243 Cedeno-Laurent F, Opperman MJ, Barthel SR, Hays D, Schatton T, Zhan Q He X, Matta KL, Supko JG, Frank MH, Murphy GF, Dimitroff CJ: Metabolic inhibition of galectin-1-binding carbohydrates accentuates antitumor immunity. J Invest Dermatol 2012;132:410-420.

244 Abu-Elsaad NM, Elkashef WF: Modified citrus pectin stops progression of liver fibrosis by inhibiting galectin-3 and inducing apoptosis of stellate cells. Can J Physiol Pharmacol 2016;94:554-562.

245 Oberg CT, Leffler H, Nilsson UJ: Inhibition of galectins with small molecules. Chimia (Aarau) 2011;65:1823. 


\section{Cellular Physiology Cell Physiol Biochem 2017;41:1801-1829

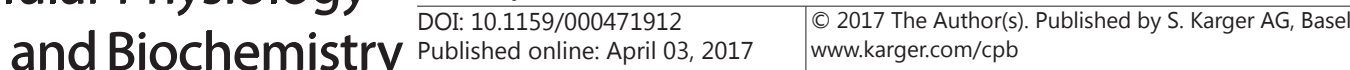

246 Maschek G, Savaraj N, Priebe W, Braunschweiger P, Hamilton K, Tidmarsh GF, De Young LR Lampidis TJ: 2-deoxy-D-glucose increases the efficacy of adriamycin and paclitaxel in human osteosarcoma and nonsmall cell lung cancers in vivo. Cancer Res 2004;64:31-34.

247 Di Cosimo S, Ferretti G, Papaldo P, Carlini P, Fabi A, Cognetti F: Lonidamine: efficacy and safety in clinical trials for the treatment of solid tumors. Drugs Today (Barc) 2003;39:157-174.

248 Morad SAF, Cabot MC: Tamoxifen regulation of sphingolipid metabolism--Therapeutic implications. Biochim Biophys Acta 2015;1851:1134-1145.

249 Pusapati R V, Daemen A, Wilson C, Sandoval W, Gao M, Haley B, Baudy A,R, Hatzivassiliou G, Evangelista M, Settleman J: mTORC1-Dependent Metabolic Reprogramming Underlies Escape from Glycolysis Addiction in Cancer Cells. Cancer Cell 2016;29:548-562.

250 Hockl PF, Wolosiuk A, Perez-Saez JM, Bordoni A V, Croci DO, Toum-Terrones Y, Soler-Illia GJ, Rabinovich GA: Glyco-nano-oncology: Novel therapeutic opportunities by combining small and sweet. Pharmacol Res 2016;109:45-54.

251 Parry AL, Clemson NA, Ellis J, Bernhard SSR, Davis BG, Cameron NR: “Multicopy multivalent” glycopolymerstabilized gold nanoparticles as potential synthetic cancer vaccines. J Am Chem Soc 2013;135:9362-9365.

252 Zhang S, Moussodia R-O, Murzeau C, Sun H-J, Klein ML, Vertesy S, Andre S, Roy R, Gabius HJ, Percec, V: Dissecting molecular aspects of cell interactions using glycodendrimersomes with programmable glycan presentation and engineered human lectins. Angew Chem Int Ed Engl 2015;54:4036-4040.

253 Rosenberger I, Strauss A, Dobiasch S, Weis C, Szanyi S, Gil-Iceta L, Alonso E, Gonzalez Esparza M, GomezVallejo V, Szczupak B, Plaza-Garcia S, Mirzaei S, Israel LL, Bianchessi S, Scanziani E, Lellouche JP, Knoll P, Werner J, Felix K, Grenacher L, Reese T, Kreuter J, Jimenez-Gonzalez M: Targeted diagnostic magnetic nanoparticles for medical imaging of pancreatic cancer. J Control Release 2015;214:76-84.

254 Danhier F, Messaoudi K, Lemaire L, Benoit J-P, Lagarce F: Combined anti-Galectin-1 and anti-EGFR siRNAloaded chitosan-lipid nanocapsules decrease temozolomide resistance in glioblastoma: in vivo evaluation. Int J Pharm 2015;481:154-161.

255 Aykac A, Martos-Maldonado MC, Casas-Solvas JM, Quesada-Soriano I, Garcia-Maroto F, Garcia-Fuentes L, Vargas-Berenguel: beta-Cyclodextrin-bearing gold glyconanoparticles for the development of site specific drug delivery systems. Langmuir 2014;30:234-242.

256 Reynolds JL, Law WC, Mahajan SD, Aalinkeel R, Nair B, Sykes DE, ong KT, Hui R, Prasad PN, Schwartz SA: Nanoparticle based galectin-1 gene silencing, implications in methamphetamine regulation of HIV-1 infection in monocyte derived macrophages. J Neuroimmune Pharmacol 2012;7:673-685.

257 Wojtkowiak JW, Cornnell HC, Matsumoto S, Saito K, Takakusagi Y, Dutta P, Kim M, Zhang X, Leos, R, Bailey KM, Martinez G, Lloyd MC, Weber C, Mitchell JB, Lynch RM, Baker AF, Gatenby RA, Rejniak KA, Hart C, Krishna MC, Gillies RJ: Pyruvate sensitizes pancreatic tumors to hypoxia-activated prodrug TH-302. Cancer Metab 2015;3:2.

258 Phillips RM, Hendriks HR, Peters GJ: E09 (Apaziquone): from the clinic to the laboratory and back again. Br J Pharmacol 2013;168:11-18.

259 Hicks KO, Siim BG, Jaiswal JK, Pruijn FB, Fraser AM, Patel R, Hogg A, Liyanage HD, Dorie MJ, Brown JM Denny WA, Hay MP, Wilson WR: Pharmacokinetic/pharmacodynamic modeling identifies SN30000 and SN29751 as tirapazamine analogues with improved tissue penetration and hypoxic cell killing in tumors. Clin Cancer Res 2010;16:4946-4957. 